\title{
Study on Vico
}

\author{
Georges Sorel
}

In 1839 Jules Michelet published an abridged translation of the New Science. In his preliminary discourse he stressed the originality and the worth of Vico's ideas. The great French historian claimed that soon the Neapolitan philosopher would be appreciated at his true value and that then it would be possible to give to the public the whole work. He thought it necessary, in the meantime, to make rather large cuts. ${ }^{1}$

Vico's work remained little known in France. It is cited almost exclusively to recall the principle of ideal history, common to all peoples and destined to renew itself eternally.-This part of the New Science is of real interest for our contemporaries, because if Vico's ideas have real scientific value, hope must be given up of the socialist transformation ever taking place.-The mythology developed in this book has been abandoned with good reason: Michelet thought it so bad that he almost completely removed it, asking the reader's indulgence for these arbitrary combinations. I believe that we ought to be 786 equally | severe when it comes to ideal history. This idea can serve no purpose and unfortunately covers over very fine theories that still today retain their importance.

In a note in Capital, Karl Marx observes the powerful interest a history of technology would hold and adds: "Darwin has called attention to the history of natural technology, that is to the formation of the organs of plants and animals understood as means of production for life. Does not the history of the productive organs of social man deserve similar investigation? And would not such a history be easier to compile, since, as Vico says, human history differs from natural history in this, that we have made the former, but not the latter?"2

This conception of the construction of history by mankind constitutes the original part of Vico's work; this is the part of the New Science that deserves to be deepened still today and that can give useful indications to the historian

1 Michelet followed the edition of 1744 even though he thought it quite mediocre.

The citations in my text all refer to Michelet's translation in its 1894 edition: this volume includes, in addition to the New Science, Vico's autobiography, the treatise on the ancient wisdom of Italy and some minor works.

2 Capital, French translation; p. 162, col. 1, note [Sorel has omitted the phrase "material basis of all social organization" after "social man." Marx, Capital, 493-494]. 
of institutions and revolutions. But in order to appreciate the full worth of the theses to which Marx refers, one must first free the path of obstacles; all the superficial parts of Vico's system must be removed, above all that which is the most famous, but which is unnecessary.

The conception of an ideal history - that is to say, of an unequivocal succession of political forms in a system, reproducing itself always in the same waywould have appealed to the spirits of ancient times because of its resemblance to the conception of the stages of individual life. When the living being dies, another replaces it and the same evolution is evident, at least until the species changes; but the transformation of species was dismissed by almost all philosophers.

Aristotle, on the basis of observation and the history of institutions, criticized Plato's theories about the order in which political forms succeed one another; he showed that, in reality, things do not develop as simply as theorists like to imagine and that [here] there is no law verified by experience. ${ }^{A 1}$

The influence of preconceived ideas is so strong that Aristotle's criticisms do not seem to have had a great intellectual influence. ${ }^{3}$ Polybius takes up again the notion of ideal history and traces a table which, according to him, represents the natural order (Book VI, $\S \S 4-9$ ), but he warns us that it is not rigorously exact. "One might be mistaken about the time, if one tries to predict the duration of this or that government, but one will rarely be wrong about the degree of growth or decadence to which it has arrived-or about the nature of the changes that it must undergo. It is above all regarding the Roman constitution that this method, wisely applied, will allow us to know origins, developments, maturity, as well as changes yet to come. For, more than any other, this republic was established and has grown according to the laws of nature; and the revolutions that await it will follow the same order" (§9). Polybius' understanding of the Roman constitution (which contains elements borrowed from monarchy, from aristocracy, and from democracy) does not allow it to be placed in the schema, which presents to us the following evolution of simple forms: arbitrary monarchy — monarchy based on universal consent - tyranny — aristocracy concerned with the common good-

3 It is, after all, quite remarkable that Greek science-for reasons that are still unclear-relies on Plato more than on Aristotle. This can be seen very well in Galen. 
oligarchy_democracy — ochlocracy dominated by the pillaging appetite of factions, until the multitude finds a leader which returns it to monarchy. What results from Polybius' text is that the Greek historian considered the Roman constitution as having lost, in his time, its ancient strength and as destined to being swept away, despite its perfection and its complexity, by the theoretical movement described above $(\S 57)$.

In Machiavelli we find this superstitious respect for formulas driven to its highest degree. In chapter two of the first book of his discourses on Livy, he copies Polybius more or less word for word and does not try at all to apply this theory to the numerous revolutions which the Italy of his time allowed him to observe. He believes that the logical development of things according to ideal relations occupies a place superior to and above observation. The old Platonic idea prevents him from establishing a social science based on the study of facts: reality in its complexity does not seem to be reducible to any exact law, for | it is but an imperfect imitation of ideal forms which, alone, are sufficiently dignified to keep the philosopher busy.

This consideration will be seen as well in Vico, who was strongly nourished by the study of Plato. The sources on which the Neapolitan philosopher worked were not very numerous. ${ }^{4}$ The history of the Orient was unknown to him; and that of the Jews systematically put aside, for the chosen people could not have developed according to the same laws as everyone else.

Among the classical peoples, he does not even find a perfect regularity. "The Carthaginians were prevented by their native African shrewdness which was further sharpened by their maritime trade. The Capuans by the mild climate and the fertility of this happy Campania ... But the Romans, having none of these obstacles, proceeded with even steps being ruled by Providence through the medium of vulgar wisdom. Through all three forms of civil states [...] they persisted in each until it was naturally succeeded by the next. They retained the aristocracy down to the Publian and Petelian laws; they preserved popular liberty down to the time of Augustus; and they clung to monarchy as long as it was humanly possible to withstand the internal and external causes that destroy that form of state. ${ }^{5}$

4 At the end of the third chapter of the first book, he cites a number of authors, who probably are the only ones that he had read concerning the mores of peoples foreign to our civilization: "for the Peruvians and Mexicans, Acosta; for the peoples of Virginia Thomas Aviot [Harriot]; for those of New England Richard Waitborn [Whitbourne]; for those of Guinea Hugues Linschotan [Hugo van Linschooten]; for the Siamese, Joseph Scultenius [Joost Schouten]." [§337]—He read no Arab geographer or historian.

5 Book v, chapter 3, p. 627 [§1088]. 
I will frequently return to the crucial role that Providence plays in Vico's sociological theory. We can already observe here that the regularity of Roman history is not explained exclusively in terms of human causes, but is connected to an otherworldly cause. The Romans had the good fortune of having instincts capable of allowing the full execution of the providential design; - the rational plan of history realized itself better with them than with other peoples.

Again, it must be added that this realization depends in part on quite an extraordinary phenomenon. Romulus, in founding Rome, opened an asylum and thus enacted an archaic creation. "He had to found his | city on the same basis that had been given to the first states [cités] of the world. Roman civilization began from this principle."6 But at the same time it had to use the language [langage] of cities in Latium that were already much more advanced. This had two important consequences. On one hand, "[Roman] heroism was young, while it had already begun to age with the other people of Latium"; and on the other hand the heroic period of the Romans was told in a vulgar language and in a form that was already partly historical.

In Greece there had been a contrary phenomenon. History, rather than being artificially lengthened, was shortened. The philosophers brought the country abruptly from a state of barbarism to the most refined civilization. The heroic era left traces only in legends, which have not even survived in their primitive form. Vico imagines that the fables were originally stories about the history of peoples. ${ }^{7}$ Later on, philosophers tried to find depth in them: "it was what was done by Manetho, great priest of Egypt, who gave the history of his country the deep meaning of a natural theology."8 In Greece, he supposed that there had been, well before the classical culture, another transformation, "the fables were changed, twisted from their first meaning, obscured in the times of corruption and dissolution that preceded even the existence of Homer. The Greeks, afraid to find the gods as contrary to their wishes as they must have been to their morals [moeurs], attributed these morals to the gods themselves and often gave to the fables a shameful or obscene meaning."9 No kind of proof is given to support this theory, which seems to be invoked here only in order to have one more reason to reject the Hellenic legends and to be able to reconstruct them with the resources furnished by Roman history. ${ }^{10}$

\footnotetext{
6 Axiom $21[\S 160]$.

7 Axiom 13. Vico has no idea of the migration of fables; he considers them autochthonous [§144-146].

8 Axiom $55[\S 222]$.

9 Axiom $54\left[\S_{221}\right.$.

10 If Vico has gone badly wrong here and makes a gratuitous hypothesis in attributing to the pre-Homeric poets such a refined casuistic - what to say about modern authors who go
} 
The ancient history of Rome does not appear as very certain until the second Punic war. Yet it does present descriptions of a general nature that allow an understanding of the evolution of customs [moeurs] and of laws. This evolution should, according to Vico, also be found in the true heroic period of the Greeks. It then becomes possible to discover, behind the self-serving fictions of the poet-casuists, the events reflected in the history of Rome before the Lex Publilia.

In order to judge this method of reconstruction, I extract from Michelet's analysis the following passage: "The pretensions of the plebeians are noted by the fables of Ixion, lover of Juno, of Tantalus still changed in the midst of the waters, of Marsyas and Linus who defied Apollo in song battle, which is to say who disputed with him the privilege of his auspices. Their efforts were not always met with success. Phaeton falls from the chariot of the sun, Hercules suffocates Anteus, Ulysses kills Irus and punishes Penelope's lovers. But, according to another tradition, Penelope gives herself to them, like Pasiphae to her bull (the plebeians obtain the privilege of formal weddings); and monsters such as Pan and Minotaur are the result of these criminal unions. Hercules feminizes himself and weaves under Iole and Omphale; he pollutes himself with the blood of Nessus, becomes mad and dies."11

It is clear that Michelet was quite inspired to dissimulate as well as he could such extravagances: they show how far a man of genius can go when he allows himself to be guided by the sophisms of sufficient reason. All that is quite well connected; origins ${ }^{\mathbf{A} 3}$ offer only, according to Vico, "incertitude and obscurity"; it is like "a field without a master, which belongs to the first occupant;" one must not settle for the opinions that have been expressed about the first forms of civilization, but bring them under "scientific principles."12

Many contemporary authors who do not have Vico's genius have proceeded just as cavalierly as he and have reconstructed for us quite satisfactory looking primitive worlds that are quite agreeable novels ... but that are, like Vico's Greek mythology, too reasoned to be realistic [trop raisonnés pour être vraisemblables]. Happily, the New Science contains theories of a | greater interest that this one and I have cited it only to show how the preoccupation with ideal history can be dangerous.

looking in the poems of the philosophical period for evidence about ancient customs? This is anyway what M. Giraud-Teulon does in claiming to find in Aeschylus' Eumenides a proof to support his matriarchal thesis. (Les origines de la famille, rre edit. p. 238). Arguments of this kind cast doubt on even the best claims. ${ }^{\mathrm{A} 2}$

11 Page $510[-511 . \S 1076]$. This fragment of the second book has been briefly analyzed separately and put in an appendix. 
According to Vico's theory, the Middle Ages ought to reproduce a second time the course of ideal history: this opinion seemed singularly paradoxical to the first writers who studied the New Science, and Michelet approved of Mario Pagano for having thought that "the second barbarism had not been so like the first as Vico seemed to think."13 Certainly in the 18th century the feudalism of the High Middle Ages was too little understood for it to have been possible to establish scientific comparisons between it and old Roman institutions. This part of Vico's work often lacks solidity. The Neapolitan philosopher did not try to find, in the medieval period, the reproduction of events that took place in Rome, and he did not try to apply to the legends the strange procedures that he had set in motion to explain Greek mythology. There is one point on which his ideas seem to have been confirmed by contemporary research. The Middle Ages indeed began with a return to the customs [moeurs] of primitive people: up to the 11th century, in order to really understand things, one must look to the customs [coutumes] of the raiding and ferocious peoples of central Africa, or those of the redskins [Peaux-Rouges]. This return to barbarism must strike an Italian more strongly than authors from countries where the tradition of the Middle Ages has left so much of a mark in the most intimate elements of modern national life. In Italy, feudalism was a sociological monstrosity.

In the New Science, Vico gives hardly any indication about the future of Europe, but we find a curious exposition in a letter written in 1726 to Father Vitré (s.J.). ${ }^{14}$ The genius of Europe seems exhausted. The classical studies that were so brilliant during the Renaissance have been abandoned. Research into law [droit] is no longer done: the experimental method is held in contempt. ${ }^{15}$ Time is given only $\mid$ to composing synopses and dictionaries to replace individ-

13 Appendice à la vie de Vico, p. 142 [This appendix was not included in the "Discourse on the life and system of Vico" translated in 2008 by Ashraf Noor].

14 Page 170 [see Pinton, "Four Letters," 42-45].

15 Here the author is alluding to Cartesians who he sees as above all responsible for the decadence of scholarship. In a letter to G.L. Esperti, he appreciates I think more justly the role of Cartesianism and says that its success has to do with the character of a "century of supercilious superficiality, in which one wants to appear enlightened [éclairé] without study" (p. 177) ["Four Letters," 36-42]: Cartesian philosophy is no longer considered here as a cause, but as an effect.

In the July 1896 number of the Revue de métaphysique et de morale, [792] one can read excellent observations from M. Lanson on the intimate relationship that existed between Cartesianism and literature of the second rank in the 17th century. The remarks, full of the wisdom of the judicious [savant] professor, confirm Vico's views. The personal genius of Descartes has nothing to do with all this, as Vico has said elsewhere (Discours sur le système et la vie de Vico, p. 11, and Réponse à un Journal littéraire, p. 168). 
ual work. The world seems to return to the practices of the late Empire. From this it is only a short step to the conclusion that the moment of a great revolution is near: but Vico does not draw the conclusion.

II

Ideal history applies very imperfectly to the reality of things, especially for the second evolution. But not everything in this notion is of equal importance. What seemed essential to Vico was the obligation to start with a government of aristocratic barbarism in order to finish with a civilized monarchical government that would apply natural equity. This is what he called law of royalty [loi royale], and he scolded modern interpreters of Roman law for not having recognized it. ${ }^{16}$

He returns several times to the law of royalty and gives several explanations. He says first: "Here is the eternal formula in which nature has conceived it: when the citizens of a democracy no longer consider anything more than their particular interests and when, to attain this goal, they turn the forces of the nation to the ruin of the country, then a single man rises up who, making himself master through force of arms, takes for himself all public matters and leaves to the subjects only the care of their own particular affairs. This revolution is for the good of the people... When citizens have thus become strangers to their own country, it is necessary that the monarchs direct and represent them."17 Here we do not quite grasp the thought of the author, who clarifies himselfpartly - in another passage: "The free power of a State, through which precisely it is free, must in some way realize itself. Thus, all the force that the nobles lose, the people gain, until it becomes free; all that $\mid$ the free people loses goes to the profit of the kings, who finally acquire monarchical power. The natural right of moralists is that of reason; the natural right of peoples [gens] is that of utility and of force."18

But we are still in the presence of purely idealist evolutions: simply because we see the suitability of something, its necessity for the health of the State, it does not necessarily follow that this suitable thing must take place. The proximal cause, the real mediation through which the change takes place, escapes us. In the first cited passage, Vico indeed says that the monarch rises through

\footnotetext{
16 Book IV, chapter 6, § 2, p. 595 [§ 1007].

17 [§1008].

18 Book v, chapter 2, p. 626 note [§1084].
} 
force of arms, but we do not see why this force is effective at this particular moment and not at another. In this second passage, he gives us arguments only of a logical order.

The detailed explication is in the fourth chapter of book five. It is one of the most important parts of the work, because it allows us to understand, in a complete way, the role that Vico attributes to Providence. The citizens want to make use of their wealth to obtain power, they trouble the peace and push the country into anarchy. "To this frightful social ill, Providence applies the three great remedies about which we will speak." Monarchy establishes itself through the force of arms and this government "is neither tranquil nor durable, if it does not know how to satisfy its people through religion and natural liberty." The second procedure is used when "Providence does not find a remedy within, she brings one from without." The people, having become slave to its passions, becomes slave of a people conquering "by the law [loi] of the right [droit] of peoples." But these two methods can be replaced by an extreme remedy: "these men are accustomed to thinking only about private interest; - - they live in a profound solitude of soul and of will. They have become more ferocious ... through intellectual [réfléchie] barbarism than they had been through that of nature." ${ }^{19}$ Civil wars devour the country: "the people become as though numb and stupid ... the small number of men who remain at the end, find themselves with an abundance of necessary things, and become again naturally sociable; the antique simplicity of the first ages reappears among them, they come to know again the religion, truthfulness, and good faith that are the natural bases of justice."

Applying these principles to the High Middle Ages, he wrote, "God permits that a new order of things be born among the nations. He brings back the customs of the first age, which merit more then than before the name divine."20

From these citations it clearly follows that the return of ideal history is a miracle and that the law of royalty is the manifestation of a providential will seeking to correct men as gently as possible.

The origins of civilization show us analogous phenomena, that is to say an ensemble of uncontested miraculous actions. History begins at the moment when our ancestors began to think like men, ${ }^{21}$ but we must ask how we can represent for ourselves these first thoughts. "In the lawless state, Providence wakes in the soul of the most violent and the most proud a confused idea of divinity, in order that they might enter into social life, and that it may introduce nations

19 [ $\left.\$ 1103^{-1106}\right]$ It must be observed here that Providence can have recourse to three quite distinct remedies, which takes a great deal away from the regularity of ideal history.

$20 \quad$ Book v, chapter 1, p. 616 [§1048].

21 Book I, chapter 4, p. $35^{8}[\S 377-378]$. 
there."22 Frightened by lightning, certain men abandon their wandering and begin to bridle their passions. They know "modesty, which, after religion, is the principle tissue of societies. Thus marriage is established, which is to say union of the flesh made according to modesty and with the fear of a god."23 Vico finds three survivals of this primitive process in marriage rites: "the first is that of the auspices of Jupiter, auspices drawn from the lightning that had decided the giants to observe them." The second consists in the veil as a memory of "this first movement of modesty that determined the institution of marriages." Finally, the Romans conserved the simulacra of the abduction [rapt], "in order to recall the true violence with which the giants carried off the first women into their caves." Juno was the first divine symbol created after Jupiter. Finally, on the basis of who knows what, the Neapolitan philosopher believes that the primitives contented themselves with only one woman for life. A third progress lead to the institution of tombs, the cause of which at first was "the need to hide objects that shocked the senses." ${ }^{24}$ Soon there arose universal belief $\mid$ in the immortality of human souls. Such are the first three principles of the New Science.

I am not going to stop to discuss this reconstitution of the past made by Vico's imagination. I only want to call attention to the impossibility of rendering these processes intelligible in a complete way without the intervention of a supernatural cause. The great merit of the author of the New Science seems to me to have been here to recognize in a perfectly clear way the conditions of the problem and not to have sought to hide the insufficiency of his theories.

Ideal history begins and ends with the miracle; but is it possible even to conceive of the uniformity, more or less apparent, of the causes of events, without the intervention of a common and superior cause? The response can hardly be in doubt. "The New Science will be, in one of its main aspects, a civil theology of divine Providence ... the philosophers have either been entirely unaware of Providence, or have considered it only in the order of physical things ... the New Science will be, so to speak, a demonstration of the fact, a historical demonstration of Providence, ${ }^{25}$ because it must be the history of the decrees through which this Providence has governed, unknown to men and often despite them,

\footnotetext{
22 Axiom 31 [§178].

23 Book II, chapter 4, p. 436 [§504-505].

24 Book II, chapter 2, $\S 1$, p. $444\left[\$ 5^{29}\right.$. This is from a section of the text considerably reduced by Michelet].

25 Michelet says that some authors have thought it possible to draw Vico together with the philosophers of the 18th century and to suppose that his Christianity was purely superficial. He thinks that this is a serious error (Appendice à la vie de Vico, p. 134).
} 
the great state of human kind."26 Providence employs the simplest means, organizes everything harmoniously, and "orders nothing that does not tend toward a greater good than what men have proposed." Following from these divine origins of history, "the destiny of nations has, does, and must follow the course indicated by the New Science, even if infinite worlds are born through eternity. In this way, the New Science traces the eternal circle of ideal history, on which the histories of all nations turn in time, with their birth, their progress, their decadence and their end."

So it seems that Vico has seen the metaphysical foundation of his ideal history perfectly well, for him this is the providential principle.

The preceding observations by no means exhaust the question, for divine action, in ancient philosophy, was understood in two ways: sometimes it corresponds to the Will [Volonté] acting with reflection, with motive and with an end in view; $;^{27}$ other times it is only unconscious force, regulating, through a fixed law, successive changes. Vico, like many thinkers, often confuses these two distinct notions. He writes that "the reader experiences a divine pleasure when he contemplates within the uniformity of divine ideas this world of nations, across the whole breadth and variety of places and times. Thus, we have proven by fact to the epicureans that their chance cannot wander according to the madness of its caprice, and to stoics that their eternal chain of causes is itself suspended in the powerful and benevolent hand of God, very great and very good." 28

When Vico denies chance, he affirms the unilateral intelligibility of historical causes, and he affirms it without ambiguity: "Can our mind [esprit] imagine causes more numerous, less numerous or other than those of which the social world is the result?" 29 He would not speak otherwise about a question of physics. When he refers the permanence of laws to the uniformity of divine ideas, he reproduces the ancient notion of the unchanging first mover guaranteeing the stability of the world.-But, at the same time, he attributes to this mover prevision, wise and good motives: in this way he distances himself from modern science and remains closed within the sphere of finalism.

\footnotetext{
26 Book I, chapter 4, p. $361[\S 342]$.

27 Here the end is "conservation of humankind." Book I, chapter 4, p. 361 [§341].

28 Book I, chapter 4, p. 363 [§345].

$29[\S 345]$.
} 
We must ask ourselves why such a discerning mind so abused Providence in his explanations. What was said in the preceding section makes it possible, already, partly to make sense of Vico's motives: scientific causes are not sufficient to demonstrate the historical laws he believed himself to have discovered. But Vico's illusion has causes of a different nature, which prevented him from seeing the truth and rigorously criticizing these theories.

It is only in our own time that it has become really clear that moral judgements do not belong to the scientific study of institutions. These are phenomena, the historian seeks to grasp fully their workings and follow their changes, but he can judge them only subjectively, according to a measure that cannot be given as scientific. Theses on progress are epiphenomenal. ${ }^{30}$ Formerly, things were understood from a different point of view: much time was spent labelling actions and then seeking the reason for this succession of moral phenomena. This reason of course escaped any scientific investigation and therefore led to the imagining of more or less supernatural causes, immanent tendencies, ideal laws of the spirit, and so on, which is to say to the creation again and again of idealist chimeras.

Vico took this as his starting point and, just as the harmonies of nature had been discussed a great deal, he gave the ethical formula that dominates all the states of humanity: this formula is remarkable because it was destined for great success in our own time, among groups that certainly do not know the New Science. The final chapter of Book $\mathrm{v}$ is given over to explaining how, from the origin of societies, power belongs to the best, forming a natural aristocracy. ${ }^{\mathrm{A5}}$

I said, above, how he pictured the formation of the first families, living, he says, in a monastic way. The chiefs of the family were at once religious and barbarians, in the grip of fanatical superstitions, like Polyphemus fearing lightning. ${ }^{31}$ Savages who remained in the plains, given over to primitive promiscuity, took refuge in strong places where the first families | lived. They worked for the masters who protected them: "strangers to modesty, they obeyed the men who contented themselves for their whole lives with a companion given to them by religion; weak and until then wanderers, they obeyed prudent men who sought

30 It must not be concluded that moral valuations are epiphenomena. This is no more correct than to say that consciousness is an epiphenomenon in psychology. Without going into details, I observe that moral valuations played a capital role in the ancient struggle of the orders and in modern class struggle. But it is because these valuations are not scientific and demonstrable that they play this role: struggle cannot be undertaken over a mechanical theorem. Moral judgements are therefore, from a certain point of view, the basis of all historical movement. ${ }^{\mathbf{4}}$

31 Book II, chapter $5, \S 1$, p. 441, Vico observes that one must be cautious about how the golden age has been described by "feminized poets" [ $\left.§ 5^{22}\right]$. 
to know the will of the gods through auspices, heroes who tamed the earth through their labors, killing ferocious beasts and helping the weak in danger." The first form of the family, purely natural, had been founded on religion and the instinct of the species. ${ }^{32}$ The second, partly civil, grew because it was useful and held within it the principles of future servitude. Here, power belonged to the fathers, "who had the superiority of sex, age, and virtue," even here it was still "the best who reigned, optimi."

The servants were oppressed and rose up: the family leaders united in order to form aristocratic political bodies, among which ruling senates formed and chose the mostly powerless kings of the heroic period. Land was given over to the plebeians, but on conditions worse than the patrician's domains. ${ }^{33}$ The nobles made "the public good consist in the conservation of this absolute power that they had originally over their families and that they maintained in the state, so that they understood the word country [patrie] in the etymological sense that it can take of the interest of the fathers." ${ }^{34}$

The plebeians wanted to participate in religious rites and in "political and private rights [droits], which were regarded as so many dependencies of it [religion]. The zeal of the people for religion also brought it to civil society." Here Providence intervenes in a truly singular way: it encourages the invention of the census, so that "industrious, economical and foresighted men ... generous and magnanimous men ... the rich endowed with some virtue or some image of virtue would be regarded as the most worthy for government, as the best."

Finally, the law of royalty and the need for conquest, in case of necessity, give the government to those who are the most capable.

Two kinds of causes can easily be distinguished in this schematic picture. | Inspired by Roman history, Vico derives many changes from the struggle of the orders. However, the crude result of these struggles repelled him: power might have been distributed by chance. So he makes Providence intervene, charged with bringing a certain moral order to the world.

To Vico, historical reasons seem insufficient to produce this order that he regarded as a postulate accepted by all philosophers. We will see the reason for this postulate in the next section.

An ethical paradox presented itself to him from the beginning: man has vices, these vices cannot be changed into virtues and nevertheless legislation makes use of these bad sides of human nature. ${ }^{\mathbf{A 6}}$ "Thus from three vices, ferocious pride, avarice, ambition, which mislead humankind, it draws the profes-

32 Book II, chapter 5, § 2, p. $445[$ [ 554].

33 Book II, chapter 6, §1, p. 456 [§597].

34 Book II, chapter 6, §8, p. 482 [§677]. 
sion of war, commerce, politics, in which courage, opulence, and the wisdom of the Statesman are formed. Three vices able to destroy the human race produce public happiness [félicité]."35 This seemed to him impossible to understand without the intervention of an exterior power: "thanks to it the passions of men-given over entirely to private interests, which could make them live in solitude like ferocious beasts - these same passions have formed civil hierarchy, which maintains human society." ${ }^{36}$

Vico's ideas are not completely developed here. Indeed, these three vices do not serve to constitute society, but civil hierarchy, the historical importance of which is no doubt great, but which can be metaphysically separated from society -in the expectation that socialism will expel the State and capitalism. ${ }^{37}$

We find a more advanced moment of the theory in the chapter on method. "Men still tyrannized by egoism follow only their own interest. Each wanting for himself everything useful without giving anything to his neighbor, they cannot give to their passions the useful direction that would bring them toward justice." Still, man can be seen continually enlarging the circle of his preoccupations: he is concerned first of all with his family, then the city, then his country, and finally "he embraces in the same desire his own conservation and that of humankind. In all these / circumstances, man is principally attached to his particular interest. It must therefore be Providence itself that maintains him in this order of things and that makes him pursue it into justice, family society, the state and finally human society. Guided by Providence, man, unable to attain everything useful that he desires, does obtain what he must have, and this is what is called the just. The dispenser of the just among men is divine justice which, applied to worldly affairs by Providence, conserves human society."38

But Vico goes still further and poses a great problem that still preoccupies philosophical thought. Men very often go where they did not expect to. "Doubtless, men have themselves made the social world ... but this world is nonetheless the product of an intelligence that often departs from the particular ends that men have proposed for themselves, which is sometimes contrary to them, and always superior. These limited ends are for it the means to attain more noble ends, which assure the health of the human race on this earth. Thus men want to enjoy brutal pleasures, at the risk of losing the children who will be born, and the result is the sanctity of marriages, first origin of families. The

Book I, chapter 4, p. 36o [Sorel's citations on this page are disorganized. §132].

[Italics are Sorel's, p. 310, § 133].

37 Book II, chapter 4, p. 639 [The force of this citation is not immediately clear. It may be incorrect, like those on either side of it. §1107-1108]. 
fathers of the family want to abuse the paternal power that they have extended over clients, and the city is born. Sovereign bodies of nobles want to give more weight to their sovereignty over the plebeians and they fall under the servitude of laws, which establish popular liberty. Free people want to throw off the obstacle of the laws and they fall under the subjection of monarchs ... Who was able to do all that? It was no doubt spirit [l' esprit], because men acted with intelligence. It was not fatality, because they acted with choice. It was not chance, because the same actions undertaken again regularly produced the same results." ${ }^{\prime 9}$ There is no doubt about how to respond: this order comes from Providence.

\section{IV}

This moral order must not, in any case, be assimilated to vulgar optimism. It is connected to a conception that is of a very great | importance in the New Science. The question is, where does law [le droit] come from? This problem is still today far from resolved.

Vico takes it as a confirmed result of the inductions made by legal scholars that "law's reason is living, imperishable ... Rights [les droits] being eternal in the understanding, otherwise put in their ideal, and men existing in time, rights can come to men only from God." 40 This reasoning must have appeared rather penetrating in the past: the same question posed itself in natural science which, it had long been thought, had to be placed outside mobility and above human experiences.

From another direction, he puts forward an extremely productive principle that is difficult to reconcile with the previous one. He teaches us to seek out the origins of our metaphysical constructions in the more or less empirical constructions of social life,- - in the same way that we find the origin of our scientific theses in observations made in the arts by technicians. He insists many times on the pre-existence of vulgar wisdom. He says that "the authors of nations are earlier by more than a thousand years than the authors of books." ${ }^{41} \mathrm{He}$ compares vulgar wisdom to understanding [connaissance] of the world through the senses and reflective wisdom [sagesse réfléchie] to intel-

39 It is not useless to observe that, indeed, this hierarchy is nothing other than that in the quoted passage.

40 Book IV, chapter 7, § 2, p. 610 [§1038].

41 Book I, chapter 4, p. $364\left[\S_{348}\right]$. 
lectual understanding. ${ }^{42}$ What Aristotle said of the individual can be said of the species: "there is nothing in the intelligence that was not previously in the senses ... The intelligence acts when it draws from what has been felt something that does not fall within the senses." ${ }^{43}$ It is from the more or less reflective or scientific practice of life that philosophers have extracted their ideas: there must be a realization before the ideation, which seems to us today to be isolated from its source.

The following passage explains his way of seeing things: "If it is certain that there were laws before there were philosophers, we must infer that the spectacle of the inhabitants of Athens coming together through the act of legislation, in the idea of an equal interest that is common to all, helped Socrates to form intelligible kinds or abstract universals, through induction, an operation of the mind that gathers together uniform particulars able to compose a kind by $\mid$ means of their uniformity. Later Plato remarked that, in these assemblies, the minds of individuals, each impassioned regarding his own interest, come together in the dispassionate idea of the common utility ... Thus was prepared the really divine definition of law that Aristotle left us: will free from passion ... Aristotle understood justice, queen of the virtues in the heart of the hero (of philosophy), because he had seen legal justice, which lives in the soul of the legislator and the Statesman, order prudence in the Senate, courage in the armies, temperance at the festivals, particular justice, now commutative as at the forum, now distributive as at the public treasury. From which it results that the principles of metaphysics, logic, and morality come from the public square of Athens. Liberty ${ }^{44}$ makes legislation and from legislation comes philosophy." $45 \mathrm{~A} 7$

Inspired by these ideas, the New Science seeks to determine the principles of law. It follows the example neither of those who want to construct law through pure reason, nor of those who pretend to limit themselves to recognizing historical facts. It reasons on institutions in order to bring out the truth, through an operation analogous to the one described above. ${ }^{46}$ Rather than consider

42 Book II, chapter 1, §1, p. 376 [§ 364$]$.

$43[\S 363]$.

44 This word is understood here in the sense of the republican State. Cf: the beginning of Tacitus' Annals: "libertatem et consultatum L. Brutus instituit." Elsewhere Vico says "philosophy is born in the popular republics." Book IV, chapter 7, § 2 p. 6o8, note [§1043]. Cf. Also the note on p. 636 [§1101].

46 "philosophy contemplates reason ...; philology studies acts of human freedom ... Philosophers have remained at the halfway mark because they have neglected to bring to their reasoning certitude drawn from the authority of the philologists: the philologists have fallen into the same error because they neglect to give their facts the character of truth that they could draw from philosophical reasoning" (Axiom 10) [§138-140]. 
one state [cité], the nations taken altogether are considered. "The principle of natural law is the just in its unity, otherwise put the unity of the ideas of humankind concerning things whose usefulness or necessity is common to all human nature ... Only Plato's doctrine presents the just in its unity. This philosopher thinks that as a measure of the true one must follow what seems one, or the same to all men." 47

He defines common sense: "a judgement without reflection, shared | by a whole order, by a whole people, by a whole nation, by the whole of humankind."48 He then says, "the common sense of human kind is the criterion indicated by Providence to the nations to determine certitude in the natural law of peoples [des gens]. This certitude is reached by knowing the unity, the essence of this law, to which all nations conform with diverse modifications." 49

But law [droit] is not composed of metaphysical beliefs, analogous to those that philosophers have sometimes wanted to base on universal agreement. It has the conditions of life for its object. To study it, one must consider what is necessary and useful for social life. ${ }^{50}$ It therefore seems that enormous differences must appear in law from one country to another and that it must bear the marks of all the accidents of economic life. Vico does not think that this is so: it seems to him that there exists a remarkable uniformity in moral rules and he does not believe that these resemblances can come from migrations. "The natural law of peoples [gens] is born with each particular people [peuple], without any of them knowing about the others. Later, on the occasion of wars, embassies, alliances, commercial relations, this law was recognized as common to all humankind." ${ }^{11}$ Relations between nations were thus an influence on the period of reflective [réfléchie] thought and served to give a solid basis to the opinion of philosophers who generalized about juridical ideas.

Nations all have a common nature, which reveals itself not only in this uniformity of law, but above all in the uniformity of thoughts applied to practical life. "All the things that occupy human activity in society are understood uniformly, but expressed with so many modifications that things can be considered from diverse points of view. We see it in the proverbs: these maxims of vulgar wisdom are understood in the same way by ancient and modern nations." 52

Note to axiom 5 , from the 1725 edition [First New Science, 53].

Axiom $12[\S 142]$.

Axiom $13[\S 145]$.

Axiom $11[\S 141]$.

Axiom $13[\S 146]$.

5

Axiom $22\left[\S_{161}\right]$. This doctrine has had a very great success in our own time among ethno- 
This established, let us turn back and try to get a general | idea of Vico's juridical concepts, starting with the principles posed at the beginning of this section. We have to understand how history must be ordered for law to exist in God and for it to be knowable by us through reason applied to the practices of social life.

1st-Acts of authority must in large measure conform to law and be able to serve as a basis for the philosopher's inductions. ${ }^{53}$ This is why the government can only belong to the best, to those who are most able to direct men. We thus find the reason for the optimism that seemed so strange in the previous section. and-The experimental foundations of ethical science must present enough uniformity that reflective thought [pensée réfléchie] will not be in danger of discovering contradictory moral principles [morales] once it has embraced a sufficient quantity of facts. These contradictions in the human spirit cannot be reconciled with the existence of law in God: it would be as though God did not exist. In the same way that there is (for Aristotle) only one unmoving mover assuring the eternal rigor of science, so too ethics must be able to be constituted in a rigorous way, grasping social truth - just as science grasps physical truth. ${ }^{54}$ It must therefore be the case that there is a common nature among peoples, a common sense, leading to a natural law of peoples. ${ }^{55}$

805 Thus we become able to conceive of the necessity of an ideal history without which law would lack the foundation we require of it.

graphers who have for a long time thought that savages formed a homogenous mass, representing primitive humanity: they mix up all the testimony of travelers, without asking why a given practice persisted here and died away there.

53 "Civil law is defined in Ulpian thus: 'a law [droit] which is not entirely separate from the natural law of peoples, which is not entirely the same, but which sometimes adds to it, sometimes removes from it.' In the part where it is the same, it is nothing other than natural law, where it is separate, it is properly civil law." (Unité du principe et de la fin du droit universel, p. 181) [See Keys to the New Science, 39-42, and "On the one principle and one end of universal law," New Vico Studies, 2003].

54 We will see further on that science, according to Vico, does not completely penetrate physical truth; I expressed the analogy here in a modern way and therefore more clearly.

55 Vico observes elsewhere that legal scholars have too much separated reason and authority "as though authority were born from caprice." (Unité du principe ... p. 182).

It is remarkable that Aristotle was so little concerned about the sovereign good in his Ethics. Barthélémy-Saint-Hilaire does not fail to reproach him on the subject. We know through Vico's testimony that it was "reading Plato that woke in his spirit the first conception of an eternal ideal law, in force in the universal city [cité] which is enclosed in the mind [pensée] of God and in the form of which are instituted all cities across time and in all countries [pays]. Here is the Republic that Plato had to derive from his metaphysics." (Vie de Vico, p. 69) [In fact page 59. Fisch \& Bergin, Autobiography, 122]. Vico is asserting his originality here, which is the search for this ideal city in history. 
3rd-Philosophers do not like to admit that their systems may be incomplete: that is especially dangerous in moral philosophy because we are used to thinking of morality as all of a piece, and because the idea of ethical development is still unfamiliar to us. These preoccupations were yet more serious in Vico's time. It would have appeared scandalous, in that period, to cast doubt on the possibility of knowing all the principles of morality. But because these principles must be discovered by induction in the study of historical movement, it must be admitted that the movement of history has already taken place in a complete way. This justified the idea of a doubling of ideal history and the reproduction of its earlier periods since the barbarian invasions.

4th-Practically all system-builders take their own age for the age when humanity finished its progression and their school for the ultimate expression of human thought. Engels wrote about Hegel: "According to all conventions, a self-respecting philosophical system must close with some sort of absolute truth. Also, while affirming that this absolute truth is nothing other than the development of logic, of history itself, it sees itself forced to put an end to this development, because it must indeed, at the end, finish the system ... The content of the Hegelian system is proclaimed absolute truth ... What goes for philosophical understanding goes for historical practice. Humanity which, in the person of Hegel, has managed to elaborate the absolute idea, must be advanced enough to realize this absolute idea in practice." Engels adds that, in the philosophy of law, Hegel was in this way led to proclaim the excellence of the Prussian monarchy limited by the "Estates-General, old-regime style, that Frederick William II promised to his subjects" and to "demonstrate, in a speculative way, the necessity of the aristocracy. 56

Vico does not escape from this necessity, which weighs on nearly all philosophers. He understands that in his time, the great States | of Europe are monarchies. ${ }^{57} \mathrm{He}$ sees not more than "five aristocracies, properly speaking: Venice, Genoa, and Lucca in Italy, Ragusa in Dalmatia, and Nuremberg in Germany. They have only a little territory." He believed that Poland and England, which "seem under aristocratic government" would soon be "pure monarchies." The most widely spread political constitution, and that of the most civilized countries, also seemed to him the most perfect. "Monarchy is the government that most conforms to human nature, in the ages when reason is the most developed." 58

56 Ludwig Feuerbach et la fin de la philosophie classique allemande, in l'Ère nouvelle; April 1894, p. 144 [Collected works 26: 361].

57 Book v, chapter 3, p. $629[\S 1092]$.

58 Book IV, chapter 6, p. 597 [§10o9]. 
It is usually objected that philosophers have an odd idea of history because they suppose that it can be exhausted. Vico is not vulnerable to this reproach because he teaches that this royal government, so well adapted to human nature, cannot last and that the world has before it an indefinite future in which other periods return. This consideration must not be forgotten when evaluating the main idea of the New Science. The conception of indefinite progress was a problem for 18th century thought, and serious difficulties presented themselves in the attempt to make it intelligible. The repetition of periods, of historical evolutions, did not present the same obscurities and could be reconciled with an indefinite age for the world — as the ancients had recognized.

$5^{\text {th }}$-Finally, the special conditions in which Vico lived and the intellectual milieu in which his mind was formed, must be taken into account. Michelet has this to say on the subject: "Meridional Italy retains this taste for universality that had characterized the genius of Magna Grecia. In antiquity, the Pythagorean school had allied metaphysics and geometry, moral philosophy and politics, music and poetry. In the 13th century, the Angel of the school [Saint Thomas Aquinas] had covered the field of human knowledge to reconcile Aristotle's doctrines with those of the Church. Still in the 17th century, legal scholars in the kingdom of Naples felt themselves alone faithful to this ancient definition of jurisprudence: Scientia rerum divinarum atque humanarum. It was in such a country that, for the first time, all the knowledge that had man for its object would be united in a vast system, which brought together the history of deeds and languages, illuminating both with a new form of critique, and which reconciled philosophy with history, science with religion."59

807 Superstitious respect for Roman law survived more in Italy than in other countries. That the natural law of civilized peoples had to be taken into account was learned from the Justinian Compilation. Michelet has just told us that jurisprudence had been made the center of philosophical studies. Vico himself was deeply influenced by this method, he did not tend to think very much about the things that were of greatest concern for writers in other countries. "His masters," Michelet says, "were Roman legal scholars, the divine Plato, and Dante, to whom his own melancholic and passionate character drew him. While the whole century threw itself down the new paths that philosophy had opened, ${ }^{60}$ Vico had the courage to return to now-scorned antiquity and to identify himself with it." 61

59 Discours sur le système et la vie de Vico, p. [11-]12 ["A Discourse," 22].

6o Michelet judges this tendency severely: "Peoples no more than individuals can give up their originality with impunity. The Italian genius sought to follow the philosophical impulsion of France and England, and negated itself" ["A Discourse," 23-24].

Discours sur le système et la vie de Vico, p. 12 [In fact 13-14. "A Discourse," 23-24]. 
It was therefore entirely natural that the history of the development of Roman law occupied a place of honor in the preoccupations of a thinker raised in this way, and subordinated to itself all questions relative to the philosophy of history. Not only was this history well known, but it was really the history of the spirit marching from barbarism to the light of reason and managing to formulate the true by its own strength. ${ }^{62}$

I believe that I have said enough to show how the providential order, which realizes itself through ideal history, is dominated by Vico's ethical preoccupations. The moral question dominates his whole philosophy of history: modern man must be in a position to know what is truly good.

Historians have today been pointed away from ethical theories because of the requirements of scholarly research. Technical necessities have had the same consequences in the human sciences as in the physical sciences. The chemist or naturalist does not ask the finalist question of why, about the harmonic reason of things and so on. He observes and he tries to discover laws. If the old philosophy of nature is dead,—at least | for scientists [savants] — philosophy of history no longer exists for scholars: it now interests only those amateurs who do Sociology or the authors of those thoughtful, wisely republican, and blissfully patriotic books that the French government supports at taxpayer expense. ${ }^{\mathrm{A} 8}$

Just as science has struck finalism out of nature, so historical materialism has eliminated the great antinomy that caused so much trouble for Vico. We no longer have to ask how order exists despite bad tendencies, because order exists only in our imagination. Engels, like the Neapolitan philosopher, notes the contradiction arising between ends that people will and the things that are accomplished, but he draws from it quite different conclusions. "The interlacing of innumerable individual wills and actions in the historical domain creates a state of things that is entirely analogous to that which reigns in unconscious nature ... Historical events seem also to be dominated by chance. ${ }^{63}$ If chance does come into play on the surface, it is nonetheless governed by immanent and hidden laws ... Individual motives, however striking, are not so important to understand as the motives that agitate the great masses, whole peoples, and, within each people, whole classes." ${ }^{4}$

\footnotetext{
62 Vico excludes the Hebrews from his study because they had supernatural assistance, as I have already noted.

63 The word chance is here opposed to "ideal and fantastical relations that ancient philosophy of nature established in order to obtain a picture of natural connections in a systematic and approximate form, substituting for missing facts with intellectual conceptions, filling gaps with the aid of imagination." (Cited article, May 1894, p. 13).

64 Cited article, May 1894, pp. 14-16 [Collected works 26: $386 \mathrm{ff}$ ].
} 
Just as in natural science the "proper succession" of things is accepted, without feeling that something should be added,- -in the same way it is no longer permissible to replace the real sequence of history with some kind of law existing in the philosopher's head. Engels signals, forcefully, the necessity of abandoning "in this field, as well as in that of nature, artificially constructed relations."

Thus ideal history has perished, overcome by the development of historical research. It is now nothing but a memory. However, the ethical problem 809 for which it was thought to be such a $\mid$ simple and satisfying solution remains entirely and cannot be set aside as outmoded. In natural science as well there is a similar sort of problem that contemporary philosophy has shown itself equally powerless to resolve. Critique of the idea of divinity has shaken the foundations of all knowledge that drew its certitude from the ancient idea of "God in nature." Science no longer seems, today, safe from contingency, the fixed point has disappeared. It is enough to read the titles of contemporary theses on understanding and contingency to understand how it preoccupies reflective minds [les esprits réfléchis]. ${ }^{\mathbf{A 9}}$

Neither does it seem easy to respond to those who want to know where law [droit] finds its place in materialist conceptions of history. ${ }^{65}$ The difficulty is the same as above: law that is immutable and rests in the divine Idea has disappeared as has science possessed totally by God. Nothing is served by denying the difficulties that result from these new principles, but this is not a reason to revive famously incorrect doctrines. The notion of ideal history was quite useful, but it is false. We will not return to it to give an illusory solution to an ethical problem that is so serious and immediate. Just because we recognize its importance we do not want to accept illusory solutions and we refuse to falsify anything in historical reality for the sake of pedagogical decorum.

Before undertaking the examination of the New Science's explicative theories, we must return to the passage to which Marx makes allusion in Capital and understand it precisely. Vico says that the origins of history are shrouded in profound darkness, but that some light can be thrown on them by beginning with this incontestable truth: "the social world is certainly the work of men; from

65 Cf. the closing observations in the curious brochure from B. Croce "Sulla concezione materialistica della storia" [See Benedetto Croce, Historical materialism and the economics of Karl Marx (London: Allen \& Unwin, 1914)]. 
which it | follows that one can, that one must, discover its principles in the modifications of human intelligence. This admitted, will not anyone who thinks about it be surprised that philosophers have seriously attempted to know the naturalworld, that God has made and whose secret he holds, and that they have neglected to meditate on this social world, which men can know, because it is their creation?"66

It was this last line that Marx found so striking. He commented on it in the following way, "technology strips naked man's mode of action vis-à-vis nature, the productive process of his material life and, in consequence, the origin of social relations and the ideas or intellectual conceptions that flow from them." 67

We cannot ask Vico to take the same point of view as Marx. Economic questions were foreign to him, even though Italians in his time had already made investigations in this order of ideas. On the other hand, he lived far from any industrial movement and in a milieu foreign to scientific discussions. He therefore could not have a clear notion of the role that Marx would later attribute to technology.

To make an exact account of Vico's thinking, we must look to the polemic directed against the Cartesians. Michelet strongly agrees with the arguments of the illustrious Neapolitan and points to his originality. "Nowhere were the abuses of the new philosophy attacked with greater strength and moderation: the distancing from historical studies, the disdain for the common sense of humanity, the reduction to an art of what ought to be left to individual prudence, the application of the geometric method to things that were hardly susceptible to a rigorous demonstration, etc." ${ }^{68}$ I pause over this polemic because M. Tocco devoted an article to it in the Revue de métaphysique et de morale, official organ of the high University of France, and this article completely and unfortunately denatured the theories of our philosopher. ${ }^{69}$

One must certainly notice the distance that Vico put between himself and the purely intellectualist and spiritualist arguments [thèses] that dominated European thought at that time. This is all the more curious | because Descartes 811 had really only given form to tendencies long latent in the world. In the scholastics there are propositions like this one: intelligence has no other reason for

66 Book I, chapter 3, p. 353 [ $§ 331$ ]. Most often Vico seems to limit his research to discovering the origins of civilization. In any case the study of origins is the most developed part of his book.

67 Capital, fr. trans., p. 162, col. 1, note [Capital, 493].

68 Discours sur le système et la vie de Vico, p. 14 ["A Discourse," 24].

69 July 1896, p. 568. ${ }^{\text {A10 }}$ 
affirming the objectivity of its perceptions than the certain knowledge [la science] that it has of its own nature and its own truth. When the reaction against the philosophical systems of the Middle Ages drove cultivated minds toward more or less mitigated Platonisms, spiritualist conceptions became dominant, dualism quietly replaced the ancient unitary theory of man and one came to conceive of the isolated intelligence reasoning alone on itself. Descartes was the first to succeed in formulating a complete system of philosophy embracing nearly the whole of the traditional encyclopedia, and presented so well that he must have hoped to see it enthusiastically welcomed by the Catholic colleges. The need for new theories was felt everywhere, and it seems that the Church ought to have been happy to find such a great and skilled scholarly reformer. Reflecting on this situation, one understands better the infinite precautions Descartes took to avoid frightening the Catholic doctors, his professions of faith, which have appeared to many people a little too passionate to be completely sincere, and the suppression of the book on Light after the judgement against Galileo. Vico pointed out quite rightly why the French philosopher presented himself as such a good Catholic. He said that Descartes' intention "was to establish his empire one day in the cloisters where, since the 11th century, had been Aristotle's metaphysics. ${ }^{70}$ To achieve this great result, it was excusable to be diplomatic. ${ }^{71}$ The Jesuit colleges were the means through which this reform could be most easily made. The Jesuits had been behind the trial of Galileo, so Descartes distanced himself - with good reason — from the ideas of the Italian physicist.

Cartesian doubt seemed to Vico really a ploy. It was not | by any such method that Descartes could have constituted his philosophy. He pretended to have swept the whole of the past away and his partisans did not bother to read the ancient authors, but he himself was quite knowledgeable [savant]. ${ }^{72}$

This appeal to individual sentiment, this pretension to reconstruct through personal effort what past generations built with such difficulty, seem to Vico ways to destroy any science. Experience had shown already that among "the Cartesians themselves, an idea that is clear and distinct for one is often obscure and confused for another."73

\footnotetext{
$70 \quad$ Vie de Vico, p. 68 [Autobiography, 130].

71 It is not easy to say why the Church has never been willing to accept Cartesian spiritualism: it had, with the scholastics, corrected Aristotle with platonic spiritualism; it could have corrected things that were too offensive, for instance relative to transubstantiation. This question was not raised in M. Blondel's article on "Descartes' Christianism" in the Revue de métaphysique et de morale, July 1896.

72 Réponse à un journal littéraire, p. 169 [Most Ancient Wisdom, 184-185].

73 Lettre à G.L. Esperti, p. 177 ["Four Letters," 37].
} 
"Skepticism," he says, "does not doubt that it thinks ... but if it is sure of thinking, it maintains that this is only consciousness, and not science, nothing but a vulgar consciousness [conscience] that belongs even to the most ignorant ... In practical life, when dealing with things of which we can give no sign, no proof, we give the testimony of consciousness." ${ }^{74}$ We would say, today, that this testimony of consciousness [conscience] seems to us all the more subjectively solid the greater the mass of subconscious memories and affective tendencies on which it draws - in a word, the more blind it is.

What preoccupied Vico was science: the sceptics that one meets in life agree with everyone about matters of opinion, of belief, but they place in doubt the results of demonstration, they agree to accept these results as long as they are advantageous. To the Italian philosopher, this is what seemed destructive of all scientific research.

One thing made a great impression on Vico: science was not born yesterday, it has a history behind it, it is only in consulting this history that we can come to know it well. It is not an object that demands personal belief or allegiance. It interests the life of man as a species and the development of humanity. It is

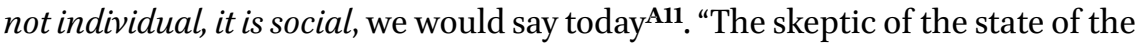
social community returns man to his solitary state." 75 There is a beautiful idea [belle pensée] that could as it stands enter into modern philosophy.

Science is the product of immense cooperative labor in which successive generations have participated. It therefore does not conform to reason to neglect the authority of tradition, which must rather be studied and discussed. ${ }^{76}$ Science does not at first appear as science. Later, Hegel would compare philosophy to the owl of Minerva that shows itself just as night begins. Vico says, "in the first times, men had to find, to invent everything necessary for life. Whoever reflects on this will find that things necessary or useful for life, and even things that are only convenient, pleasing, or luxurious, had already been discovered by the Greeks before there were philosophers ... The first peoples, who represent for us the childhood of human kind, therefore established the world of arts. The philosophers, who came long after and who represent old age, established the world of sciences, which completed the system of civilization." ${ }^{77}$ This process is not limited to the origins of humanity. It is through art that humanity prepares its scientific knowledge. Vico says again: "Those who have written about inventors teach us that all the arts and conveniences of life, whose work has enriched

74 De l'antique sagesse de l'Italie, chapter 1, § 2, p. 225 [Most Ancient Wisdom, 54-55].

75 Letter of 1729 to D. Francisco Solla, p. 173 ["Four Letters," 50].

76 Réponse à un journal littéraire, p. 168 [Most Ancient Wisdom, 183-184].

77 Book II, chapter 3, §6, p. 431 [§ 498]. 
human kind, have been found either by chance, or by comparisons drawn with animals or other parts of human industry."

There are many important observations to make about these texts. If arts precede sciences and serve as their preamble, then we must recognize that this chronological anteriority should be translated into metaphysics as a law posing technology as the basis of all possible ideologies. Vico does not draw this conclusion, but we find it expressed in a very precise way in the passage from Karl Marx mentioned at the beginning of this section.

And then, if topic precedes critique, as Vico says, if history, tradition, authority, have such great importance in the formation of science through reflective thought [pensée réfléchie], one must think that man does not place himself, 814 as philosophers ordinarily say, | face to face with nature, to observe and know it. Rather, the scientist [savant] works on a material that has been provided for him by previous generations, material belonging to what we would today call the artificial milieu. It is therefore in a milieu made by humanity that we practice induction and not in the cosmic milieu. This conclusion is much clearer for us today that it could have been in the 18th century, which had no idea of scientific industry, which is to say industry formed by the successive contributions of inventors, having acquired an anonymous or social character thanks to the multiplicity and variety of combinations realized in it. ${ }^{79}$

In passing from empiricism to reasoned understanding, from practice to science, we move only within a historical order founded on human ideas. "The New Science proceeds by a severe analysis of thoughts about what is useful or necessary to social life, ${ }^{80}$ which are the two natural sources of the law of peoples. Understood in this way, the New Science is a history of human ideas, according to which it seems the metaphysics of the human mind must proceed. If it is true that the sciences must begin from the same point as their subject, metaphysics begins at the era in which men set themselves to thinking in a human way and not when philosophers begin to reflect on human actions." ${ }^{81}$ At the origin one finds a metaphysics of the imagination, connecting barbarians and children, later on more elevated forms of reasoning appear, from the syl-

78 De l'antique sagesse de l'Italie, chapter 7, §4, p. 272 [Most Ancient Wisdom, 102]. Doubtless this is what M. Tocco is thinking of when he says that "Vico prefers to minute analysis creative synthesis, to distinct ideas the half-light of divine intuition." (art. cit., p. 569).

K. Marx says: "A critical history of technology would make clear how little it was generally the case that inventions in the 18th century were the work of single individuals." (Capital, p. 162, col. 1, note) [Capital, 493].

8o Compare to K. Marx's idea about economic infrastructure. The step taken by the author of Capital is considerable and related to the extraordinary development of modern industry he had before him.

Book I, chapter 4, p. 364 [§347]. 
logism (which seems quite poor to Vico) to induction from which "the English draw such great advantage in experimental philosophy." 82 This whole operation never takes us outside the artificial milieu. Understanding perfects itself in accordance with the law of metaphysical progression proper to the human spirit, but it always remains social, so that today "humanity is its own work." This is, as Michelet says, "the watchword of the New Science." 83

This homogeneity of process allows us already to understand that science must participate, like art, in the categories of invention, combination, and action.

In Vico's time, arithmetic and geometry were regarded as complete and perfect sciences. There was no clear idea of their origins in experiment and it was believed that they had emerged fully formed from the human brain. Our philosopher therefore says that the scientist [savant] created, without material, abstractions forming the pure elements of mathematical science: "he constructs a world of forms and of numbers that he can embrace entirely"; 84 - "the human spirit contains elements of truths that it can order and harmonize and out of the arrangement of which comes the truth that it demonstrates: it follows that demonstration is a creative operation and that the true is identical with the made." 85

Physics seemed to Vico quite inferior to mathematics because it could not become entirely human; "physics will be true for me when I have made it; just as geometry is true for men because they make it." ${ }^{\prime 66}$ As for interrogating conscience, like Descartes, it seems to Vico entirely deceptive; "the criterion of the true is to have made it; in consequence the clear and distinct idea that we have from our own mind is not a criterion of the true; it is not even a criterion of our own mind, because in knowing itself [se connaissant], the soul does not make itself and since it does not make itself it does not know [sait] the way in which it knows itself [se connait]." 87

Vico says that God knows the things of the world through their causes, - - this is the traditional doctrine. Physicists cannot pretend to recreate the world, the

82 Book II, chapter 3 , $§ 6$, p. 204 [Sorel gives the wrong page number: it should be page 433 . $\S 499]$.

83 Avant-propos, p. 3. He adds, "social science dates from the day when this great idea was expressed for the first time. Until then, humanity thought it owed its progress to the luck of individual genius." [Michelet is here quoting himself from the opening pages of his earlier Histoire romaine].

84 De l'antique sagesse de l'Italie, chapter I, §1, p. 221 [Most Ancient Wisdom, 50].

85 Id., chapter 3, p. 236 [65].

86 Id., chapter 7, p. 276 [104].

87 Id., chapter 1, § 1, p. 221 [The quote actually appears on page 222. Most Ancient Wisdom, 52]. 
elements are outside of them. ${ }^{88}$ It follows that Descartes' deductive method is only a pseudo-geometry. Opinions founded on observation must satisfy us. But to observe, we divide what was unified. "This being, this unity, this figure, this movement, this body, this intelligence, this will $\mid$ are otherwise in God, where they are one, than in man where they are divided..$^{89}$ They live in God and in man they are dead."90 True science must be able to model itself on that of God, which is composed of causes. ${ }^{91}$ "To know [Savoir]," he writes, "is to know [connaître] the way, the form in which things are made." This knowledge [savoir] exists completely in mathematics, but it is missing in physics: we can nonetheless approach it through experimentation, of which Vico has only a very imprecise idea and which he calls an imitation of nature. ${ }^{92}$ Still he recognizes its importance and considers it the basis for ascribing superiority to certain doctrines rather than others.

Today, we can make for ourselves a more exact idea of the conditions of science. We no longer see any essential differences between geometry and rational mechanics, nor even between the latter and mathematical physics. In all these cases we know that one begins with what is given by experience [expérience] and obtained through induction: ${ }^{93}$ the axioms of geometry do not escape from this universal law, which dominates all scientific research. With these elements we construct something that really is ours, which is our creation and which, in consequence, is at once the true and the made, as Vico says. When we conduct an experiment [faisons une expérience], we do not imitate nature: we make use of combinations, tools, which really are ours. We try to produce movements which never take place in the cosmic milieu. Experimentation is therefore a

88 Id., chapter 3, p. $236\left[65^{-66}\right]$.

89 M. Tocco is wrong to say that man must reconstruct what he has divided (art. cit., p. 571). That is quite wrong. One must construct with human elements, make human combinations, in order to reach the true. It is not a matter of succeeding analysis with synthesis, anatomy with physiology (as M. Tocco says), but of emancipating oneself from natural conditions.

90 Id., chapter 1, §1, p. 219 [Most Ancient Wisdom, 49]. Here Vico says that we divide man into body and soul and the soul into intelligence and will; this analysis of psychology is the source of what follows.

$91 \quad$ Id., chapter 1, §3, p. 227 [56].

92 Id., chapter 1, § 2, p. 225 and 229 [54-55 and 58].

93 Vico understands very well that geometry applies to particular questions of physics and founded on experimental laws can be of great help: he cites the example given by Galileo (id. chapter 7, p. 274 [103]). Today, the mathematical physics created by Galileo and our great Pascal proceeds in the same way. The Jesuits seem still to want to persecute the latter. The new spirit prefers Descartes: see in the above-cited number of the Revue de métaphysique (page 488) a regrettable insult addressed by M.P. Tannery to "the author of the Provinciales" ${ }^{\prime 2} 2$ 
creation, ${ }^{94}$ it belongs entirely to the artificial milieu: it is at once the made and the true. | Experimentation differs from mathematical exposition by the same difference that exists between mute language (to speak like Vico) and spoken or written language.

In modern science, the search is always for rigorous experimental determinism, with the character of an automatic machine, analogous to those that industry presents to us. It is by the perfection of this tool [outillage] that the value of the proposed physical law is judged. With only simple observation at one's disposal, nothing certain can be obtained. On this point, Vico saw correctly: we know how phenomena develop only in cases-more and more numerous-in which we control this development artificially. So the Italian philosopher is therefore right to be wary of the testimony of the consciousness [conscience]. The so-called psychological experiments undertaken with such enthusiasm by our contemporaries have produced more absurdities than could be found in peasant tale-telling. ${ }^{95}$

We will never really know the cosmic world, but we must know the artificial world because we make it - on the first we can have opinions and form hypotheses, the second gives us science. Claude Bernard ${ }^{\mathrm{A} 14}$ has expressed similar ideas, which it seems pointless to review. It is however interesting to note how little modern thought has been able to add to Vico's claim. The latter has only been clarified and given precision.

Study on Vico ${ }^{96}$

(Suite)

In the previous section I presented this fundamental formula from Vico: "the new science is a history of human ideas according to which it seems that the metaphysics of the human mind [esprit] must proceed." This proposition was singularly daring in a time when psychology had not been seriously studied and when it was believed that a great discovery had been made in basing it on personal sentiment. It was at that time impossible to have a scientific idea of the objective laws that Vico announced: our philosopher was himself wrong at

94 Cf. Capital, p. 16, col. 2 [Capital, 133 ff.].

95 The books written by the best-known authors (MM. Beaunis, Féré, and Binet) are full of foolishness that is worth no more than the boasting of the spiritists. ${ }^{\mathbf{A 1 3}}$

96 See October issue. 
every step of his research, but great men are fortunate in that even their errors are fertile and worth studying with care.

In the course of this study I will often make use of the principle enunciated in $\S$ IV on the formation of philosophy under the influence of the spectacle offered by the practice of political life. This law is of the highest importance and a whole branch of psychology could be constituted with it as a foundation, so I propose to call it Vico's ideogenetic law. I must draw attention to a passage in Capital in which the role of this law is indicated unmistakably. At issue is value, and Marx asks himself why Aristotle was not able to discover the relationship that exists between value and "indistinct human labor." The reason, he says, is that "Greek society had as its foundation the natural inequality of men, ... $\mid \ldots$ the secret of the expression of value, the equality and equivalence of all labor, by virtue of being human labor, could be deciphered only when the idea of human equality had already acquired the tenacity of a popular prejudice." ${ }^{97}$ This popular prejudice belongs to the juridical order and could only be produced through history, by the forms of civil justice and the theories of law professors.

It would be easy to bicker with Vico over facts. He could not know Roman history as we know it today, and above all its facts could not appear in the same light as they do to scholars today. It would therefore be beside the point to engage in a detailed critique of his historical expositions. I will make repeated use here of notes taken in the course given by M. Flach at the Collège de France on primitive institutions ${ }^{\mathbf{A 1 5}}$. These lessons have dealt thus far with only a limited number of known peoples, but they already contain a number of general observations of great interest.

Vico is not always faithful to his own method of historical observation. Often, he contents himself with remarks belonging to superficial psychology and applies them to the interpretation of ancient facts. He was not the last to do so. Here, for example, is how he explains the origin of religious sentiment: "man, not hoping for any help from nature, brings forth from his own desires something supernatural that can save him ... One observation that supports this idea is that libertines, who grow old and begin to feel their natural strength failing, generally become religious." 98 Obviously there is no comparison to be made between primitive peoples and elderly 18 th century libertines, who have after all received a Christian education and live in a milieu entirely suffused with Christianity. We know the extreme importance of the recall of abstract

97 Capital, p. 23, col. 2 [Capital, 152].

98 Book I, chapter 4, p. $359[$ [\$339]. 
formulas learned in childhood and what a decisive difference they can make during life crises. Nothing similar could take place for beings who do not yet think in a human way, which is the case with these primitive peoples according to Vico's hypothesis. They live like beasts and it is when lightning strikes for the first time that they remark on the existence of the sky. ${ }^{99}$

Vico several times bases his reasoning on observation of the ignorant population of the countryside. Doubtless, they offer certain remarkable analogies with the half-wild tribes of old heroic Greece: "The heroes were barbarians, proud, difficult, obstinate in their resolutions and at the same time very changeable. This is not contradictory. You can observe the stubbornness of our peasants, giving way to the first reason given to them, but through weakness of reflection forgetting quickly why they changed and returning to their earlier idea."100 Here the reason for the analogy is the weakness of reflection that, indeed, exists in both cases. But in another case quite contestable principles are derived from a mistaken comparison: "the physics of the ignorant is a vulgar metaphysics, in which they relate the causes of phenomena that they do not understand to the will of God, without considering the means employed by this will."101_-"In the beginning men, still simple and coarse, in good faith divinized whatever excited their admiration, now a virtue, now a helping power, now the goodwill of those who had civilized them."102 "Once our intelligence is raised in admiration ... curiosity, daughter of ignorance and mother of science, brings us to ask: what does this phenomena mean?"103

Do we really see, among primitive peoples, this psychology of the ignorant having received the rudiments of religious philosophy living side by side with the scientist? Vico supposes that savages already have very developed ideas about religion, and one cannot attribute such ideas to beings he represents as analogous to animals.

Curiosity is not only the daughter of ignorance. It supposes a whole body of acquired knowledge perhaps in the scientific realm or perhaps rather in that of the imagination. Hegel is right when he says, speaking about primitives: "Here we have | man with his own immediate strength [force], with his desires, with

99 Book II, chapter 2, §1, p. 383 [ 3377 ]. Vico supposes that for a long time the earth was too humid for storms to take place. This bestial state would [908] have lasted a century after the universal flood and would have been a degeneration provoked by their savage life (axiom 42) [§195].

100 Book II, chapter $7, \S 3$, p. 490 [ [ 708]. There is a similar comparison in Aristotle. (Politique, book II, chapter 5, §12) [Politics, 48-49].

101 Axiom 33 [§182].

102 Axiom $38[\S 188]$.

103 Axiom 39 [§ 189]. 
activity and the immediate relations of his will. Man does not yet ask himself theoretical questions such as: what did that, etc.? He does not yet distinguish in objects what is essential, causal, caused, and the effect."104

Much more frequently Vico compares historical development to the individual development of man. This is a very old idea, which draws the Neapolitan philosopher into singular errors. It seems to him evident that the primitive world must reproduce the characteristics that we see today in children.

"It is usual for children in their games to take inanimate things and to speak to them like living persons. Men of the youthful world [monde enfant] must naturally be sublime poets" because "the most sublime effect of poetry is to animate and impassion insensible things." 105 But why do children not make sublime poetic combinations? Who teaches them to address inanimate things in an imagistic language? Is this not something learned, like all contemporary language?

It can be admitted, to some degree, that primitives, like children, transport "the idea and the name of the first things that they see to all the things that resemble them." ${ }^{106}$ Indeed, it can be seen that there is a common cause here: both have at their disposal only a very imperfect verbal mechanism and take no interest in the differentiations that scientific understanding will reveal later. ${ }^{107}$

Some comparisons are less satisfying: "In childhood, memory is very strong; also the imagination is excessively lively, for imagination is nothing other than memory with extension or composition. And that is why we find such a strikingly true character in the poetic images that the world formed in its youth."108_ "Children have a great capacity to imitate. Everything that they 910 can already understand, they like to imitate. When | the world was young, there were only poetic peoples. Poetry is nothing but imitation ... all the arts ... were discovered in the poetic eras ...; arts are only imitations of nature, ${ }^{109} \mathrm{a}$ real poetry, if I dare say it."110__Languages must have begun in monosyllables.

\footnotetext{
104 Philosophie de la religion, fr. trans., vol. II, p. 53 [Lectures on religion, 224-225].A16

105 Axiom 37 [\$186].

106 Axioms 48 and 49 [ $\S \S 206-210]$.

107 Vico nonetheless seems here to separate better than in other cases the primitive and the child, because he speaks of the first in axiom 49 and the second in axiom 48 .

108 Axiom 50 [§ 211].

109 Vico does not explain what imitation is. When he speaks of men, he understands by it adaptation to human needs, which is something quite different from imitation proper, which children do. M. Flach says, "Nothing is done through imitation, but through transformation" (Lesson of March 11, 1896). On the difference that exists between tools of human technique and natural origins, see Reuleaux (Cinématique, fr. trans., p. 554) [Reuleaux, Kinematics of machinery, $5^{25-526] . A 17}$

110 Axiom $5^{2}[\S 217]$.
} 
Still today, with such a capacity to learn articulated languages, children, whose organs are so flexible, always begin in this way."111

Psychological analogies of the sort discussed thus far sin by omitting the historical conditions of development. Although it is always dangerous to pass from biology to sociology, it is not useless to recall here that an analogous question played an important role in zoological discussions. As is well known, parallels have been established between phylogenetic development and the development of the embryo, and it has been claimed that the latter reproduces the whole chain of ancestral species. F. Müller has observed that historical documents are often erased because the embryonic process takes a short cut, and often falsified because of adaptation to conditions during the existence of the larva $^{\mathbf{A 1 8}}$. Savage peoples have a history, which appears much more complicated than had been understood before, and they have engaged in a variety of different struggles. This history and these struggles are manifest today in psychological consequences observed by travelers who have a difficult time understanding mental states and ways of reasoning so different from our own. These difficulties would be in large measure overcome by taking on board the principles of historical materialism, and by not always assuming, in an unconscious way, that man is nonetheless always identical to himself, and that his system of ideas is independent of the particular needs and wants that result from his way of life.

Real psychological laws do not bring together things of different kinds, between which no apparent link can be $\mid$ grasped: coincidences, analogies, cannot constitute scientific laws. In many cases, psychology can easily determine the diverse aspects of a consistent group of states of consciousness through observations made here and there. Thus Vico can say: "Once men have allowed their soul to be overcome by a superstition full of terrors, they connect back to it everything that they can themselves imagine, see, or do."112

But what most characterizes psychology is the existence of laws of sequences, which define the evolution of states through which the mind [l' esprit] passes in a uniform way, going from affective and unreasoned origins to intelligible and scientific developments. M. Ribot's most recent book on the sentiments is largely given over to a description of these transformations, which are of great importance and to which Vico continuously calls attention when he speaks to us about divine, heroic, and human states. ${ }^{\mathrm{Al9}}$ There is considerable difference between the modern point of view and Vico's. He believed that psychological evolution took place in one mass, across the whole of society and developed

111 Axiom 6o [\$ 231].
112 Axiom $34[\S 183]$. 
exactly as the history of the peoples themselves. Once complete, it could not be reproduced unless history itself began again. Today we see things quite differently: psychological evolutions are sequences with their own existence and autonomy, arising in any era, mixing in society in the most confused way. Rather than a homogenous bloc, we have an interlacing of evolutions, which cannot be brought under any general definition because at any given instant we find them at all moments in their development. But economic conditions, social relations, all the historical complexes act on these evolutions to favor certain developments.

This analysis of history is of the first importance for interpreting facts according to the doctrine of historical materialism. Indeed it seems on first view that in abandoning the idealist viewpoint, one suppresses any possible science. If there are only facts, which can be known only in an empirical way, we might well ask what interest the spirit [l'esprit] could have in these mountains of historical atoms. This is why Véra sees idealism | as an obvious necessity. ${ }^{113}$ And it is for the same reason that according to M. Jaurès everyone agrees that the movement of humanity has a determined direction. ${ }^{114}$ No doubt in this way history can be made intelligible, but it is also-and this is of some importance-falsified.

Vico saw very well that events had to be combined: he saw very well that they have to be assembled, according to what is concrete and living, according to what is human, which is to say the laws of psychology. That he did not succeed in his attempt is not important, his glory is secured by having recognized that history has an identity of substance. ${ }^{115} \mathrm{Of}$ course he did not understand this identity of substance exactly as do the moderns; but it was not yet possible for him to take, in the first half of the 18th century, the path that Marx would point out in the middle of the next century, a path that even today is little traveled and ill-defined.

In his response to criticism made against him in the acta eruditorum, Vico says that the essential object of his research is the common nature of nations, but he does not say what makes this unity.116 At the beginning of the fourth book, he sets out the tripartite division that he adopts for the exposition of historical movements: "These three sorts [sortes] of unities of kind [espèces], with many others which follow from them, themselves make up a general unity of religion honoring Providence. There is the unity of spirit which gives form and

\footnotetext{
113 Philosophie de la religion, Hegel, translation: introduction to the second volume, p. $\mathrm{cv}^{\mathbf{A 2 0}}$

114 Idéalisme de l'histoire (Jeunesse socialiste, jan 1895 p. 20). [Jaurès, Rallumer tous les soleils, 238].

115 Book v, chapter 3, p. 631 [§1096].

116 Notae in acta eruditorum Lipsiensia, p. 202 [See Verene, "Vico's reply," 151].
} 
life to the social world." In the last chapter of Book Five, he returns to this point and says, "the first governments, founded on belief in Providence, had religion for their entire form, and it was the only basis for the state of the family. Religion was still the principal foundation of heroic governments ... If religion is lost among peoples, they have no way left to live in society. They lose at once the connection, the foundations, the defense of the social state, the very form of the people, without which they cannot subsist."117

It was natural that Vico would place religious ideas at the first rank because it is in religion that the autonomous existence of psychological causes appears most clearly. ${ }^{118}$ Today we can raise ourselves to a more general point of view, and include in this historical substance the whole breadth of manifestations of human activities, in as much as they are related to the laws proper to the development of the spirit [l' esprit]. Among all the various succeeding facts, we finally find a human connection that gives them a true fundamental unity, hidden from the eyes of the superficial observer.

No doubt we have once more lost the hope of unifying things according to abstract formulas, of constituting a historical science analogous to some one of the physical sciences. Yet this negative result is a guarantee for us of the value of the considerations proper to historical materialism. Rather than a false unity, we have found the concrete and living unity of man obliged to follow certain paths, always the same, to raise himself to intellectual understanding and to renew his history constantly without ever exhausting it. ${ }^{119}$ We know, today, that historical laws do not translate the effect of a cause, but give a false unity to an infinite complexity of causes: what they describe never takes place again and never has taken place, because in order to reproduce such complex combinations, whose coincidence is so accidental, is completely improbable. We no longer seek unity in the immanent tendencies of man, imagined | in order to

117 Book v, chapter 4, p. 641 [§1109]. Vico calls civil institutions materials [matériaux]: "religions, languages, lands, marriages, proper names and weapons or emblems, finally the magistracies and laws." These materials already exist before political organization, as things proper to the individual (book II, chapter 4, §5, p. 467) [§630], it is in consideration of the passage from the individual to the social that they are considered as matter [matières].

118 It is even possible to observe today that religions reproduce in a particularly striking way the evolutions that bring man from affective to intellectual life. One may say that any psychological phenomena is above all visible in the religious domain.

119 I have already mentioned Vico's particular position on progress. Michelet says that, in the first edition, our author had "hoped for humanity a stationary perfection. This idea, that so many other philosophers would repeat, does not return in the following editions." (Discours p. 18 ["A Discourse," note 7,48 ].) This remark is significant. It shows that Vico understood the innovative character of the doctrine that would produce the New Science. 
give shape to the appearances of history, but in psychological evolutions, which are hidden under the cover of historical laws.

\section{VII}

Two categories must be carefully distinguished from one another in the explications that Vico gives of the development of the human spirit [l' esprit]. Sometimes he begins with his ideal history and arranges psychological phenomena in accordance with his assumptions; - other times he takes as starting point empirically and historically observed facts, and he tried to make sense of their causes. Finally, he sometimes fills in his research with remarks about the states of mind that he recognizes in his contemporaries: such attempts are not the most successful and I have already pointed out several mediocre examples in the above section.

When the evolutions are related to divisions in ideal history, they are not very precise because these divisions sometimes extend for inordinate lengths of time. The first period (divine) corresponds to the Greek golden age and to the Latin age of Saturn; the second (heroic) is characterized by Hercules, Orpheus and other "ideal types of the founders of societies and theological poets;" the third dates in Greece from the first Olympiad. ${ }^{120}$

I begin with the examination of the sentiments. This part is, certainly, the easiest and that in which modern psychology can give us the most helpful information; - in any case Vico recognized very well that the "principles of ideal history" consist in the study of transformations in sentiments. The Neapolitan philosopher must have been lead to this point of view by the moral considerations that were so important for him. "Governments," he says, "must be in conformity with the nature of those who are governed. From which it results that the school of princes is the science of the customs [moeurs] of the people."121

He does not examine the evolution of sentiments in a purely psychological way. He does not ask how they unfold in all normal development conditions, which | would be the proper object of a science of the spirit [l' esprit]. He examines the sentiments as he finds them (or believes that he finds them) in typical history. And he does not propose to distinguish between psychological laws, which produce (or tend to produce) uniform developments, and the social conditions that accelerate, slow, limit, or snuff out growths that are too weak. As noted above, historical documents are often falsified: this is true above all for

\footnotetext{
120 Book I, chapter 1, pp. 296-300 [§61-95].

121 Axiom 69 [\$246-247].
} 
sentiments. If we can consider their evolution as regulating "the principles of ideal history" it is above all because they represent perfectly the whole group of internal movements that remain obscure and sometimes elusive for the historian so preoccupied by events.

M. Caird has observed that there has been much confusion about the role of metaphysics: metaphysicians have less invented than put into form and given a methodical exposition of ideas that exist in their milieu. "What is really due to metaphysics is not the error, it is rather this clarity and determination in the expression of the error, which is in fact the refutation of the error and which makes possible a higher point of view."122 The idea becomes therefore not the first mover, but the final product of a given civilization.

We can say something analogous about sentiments. They mark, sometimes with infinite delicacy, the states through which a people passes. ${ }^{23}$ They provide excellent explications for the movements and resolutions of individuals. But they must, in turn, be connected to the general conditions of existence. Sentiments do not make themselves, and it is difficult if not impossible to act on them through education, in an effective and durable way, if social relations are not favorable to their unfolding. ${ }^{\text {A21 }}$

Vico's theories are not always satisfactory from this point $\mid$ of view. The different sentiments succeed one another in an artificial order and are detached from their historical lineage. But it seems to me that the Neapolitan philosopher is still quite superior to our modern authors, who ponder abstract man by enclosing him in a skeleton of vaporized sentiments. Sociology has retreated a long way.

In a lecture on idealism in history, M. Jaurès details for us one of his sociological conceptions in which sentiments are considered with as little reality as possible. "What was cannibalism?" he says, "It was doubly contradictory: for in obliging man to kill man even outside the excitation of combat, it did violence [to] the first sentiment of sympathy: moral contradiction. And more, it made of man, who has a certain aptitude for regular labor, production, a sort of beast of prey whose flesh only was useful: economic contradiction. It follows that slavery had to be born, because the domestication of man wounded the instinct

\footnotetext{
122 Cited by M. Fouillée (Le movement positiviste et la conception sociologique du monde p. 270).

123 This delicacy of measure has serious consequences: it is not possible to attribute a uniform sentimental character to a long period, as Vico does. This denatures the procedureotherwise so precise - that had been adopted to characterize phenomena. Vico's error is all the more excusable because historians have continued to follow the same procedure and to speak about sentiments in a vague way. I think, however, that in order to arrive at really scientific precision, to the naming of sentiments must be added an exposition of the principle economic conditions.
} 
of sympathy less and was more in the master's interest, in drawing from man, through labor, much more than his substance could give."124

It would be useless to ask for historical proof in support of such a poetic conception. ${ }^{125}$ The instinct of sympathy and the aptitude for labor are not the motors of man: these things exist only for reflective thought, for the scientist. Moral contradictions bother only the philosopher, economic contradictions appear only to the economist and, as Vico says, such thinkers came only long after the formation of the classical institutions.

Let us pass now to examine the principles of ideal history:126 axiom 66 is conceived thus: "Men feel first the necessary, then pay attention to the useful, then seek out the convenient. Later they love pleasure, abandon themselves to luxury, and come finally to be tormented by their wealth" [\$241]. In our societies, which are developed and divided into classes, these phenomena do not present themselves in an ordered succession, but $\mid$ are found all at the same time. The sequence must be rediscovered in the history of a given class.

In wealthy classes, luxury and even waste, which Vico describes in terms borrowed from Sallust, appear well before the needs of hygiene and even comfort make themselves felt. ${ }^{127}$ Apologists of capitalism often observe that the worker (in certain places at least) has at his disposition conveniences in everyday life that were unknown to even persons of importance a century ago. Property in bodies finally disappeared in France in the grand siècle [17th century]. Urban hygiene could not be improved until the terror of epidemics overcame old habits. As for domestic hygiene, some time yet will be required before it is widely practiced.

In this way Vico was able, it seemed to him, to appeal usefully to phenomena that could easily be observed in children and peasants. Both, through lack of reflection and foresight are drawn above all to luxuries and to spend on festival days without counting. Here sentiments aroused by economic relations must be brought to bear. The peasant, like the savage, in the past did not know how to count. He had only a confused idea of the conditions of production. He did not compare the troubles he brought on himself with the satisfactions of the foolish self-regard [amour-propre] that led him to drink his wine. The

124 Loc. cit., p. 24. Certainly orators' texts cannot be the basis for scientific discussion. I would not cite this passage if the scholastic form given to the exposition did not indicate the author's clear intention to affirm doctrine: this is not a simple resort to metaphor, as might result from a quick reading.

125 To speak of constraints exerted on human instincts by a sociological entity requires a singularly mythological conception of history.

126 Axiom 68 [ $§ 243-245]$ will be discussed separately at paragraph Ix.

127 Divitias suas trahunt, vexant [Sallust, Bellum catilinarium, 20]. 
development of markets insinuated the idea of value everywhere: the transformation has been greatest in countries where agriculture is mixed with industry, because the wage regime puts the peasant-worker in the presence of two categories of price and labor time and presents them to him in a profound union.

But this is only one element of the question: progress in understanding of value, in calculating bills, hardly constitutes more than formal progress. There has been a series of transformations of different sorts that have eliminated, in part, the peasant stupidity that appears so starkly in the taste for trials, the rapid destruction of what has been constructed with such difficulty, the barbarous egoism of the master of the house, and many other attractive qualities lauded by the moralistic and conservative writers. These changes cannot be explained by psychology. They derive, as everyone | understands, from new ways of living. And these are intimately connected to contemporary conditions of production. Among these conditions the first and most important to highlight is the clearly understood possibility of improving the family budget by the intensification of labor,-abandoning routines and the desire to pursue new methods practiced by progressive cultivators, - the requirement of better appreciating the role of each particular enterprise,- - greater care given to maintaining specialized tools, - the habit of working more quickly and of combining kinds of work in order to reduce wasted time during the day.

Thanks to all these changes a more intimate union than could have existed before was formed between man and the products of his labor. ${ }^{128}$ In the passage through commercial production, man came to understand better the usefulness of different things. Different moments of this process ought to be put in place of Vico's formula, certainly a great many types would have to be identified in order to look into the question carefully.

Axiom 67 is a little more satisfying than the previous one: "the character of peoples is first cruel, then severe, then gentle and benevolent, then friend to study, finally dissolute." ${ }^{129}$ Manifestly, the first three states form a homogenous sequence, but the other two are here only in order to embrace the whole of Roman history in one schema. It is, anyway, quite difficult to say exactly what is meant by the character of a people: sometimes it means what is most widespread, sometimes what exerts the most influence on institutions.

128 This is a point that has not always been taken sufficiently into consideration in discussions around historical materialism and the influence of the economy. Changes in armaments have often exercised a decisive influence in the course of history, in periods when the instruments of labor were stationary, and such changes must be taken into consideration as progress in dominant tools.

129 [ 242. Michelet has given "ami de la recherche," which is translated here, whereas the Italian has "dilicata," i.e. delicate]. 
Certainly, a taste for study and dissolution can be discovered in civilizations that are not very advanced in cultural terms and whose customs have remained rather primitive. These two characteristics ought to be examined more closely, because eroticism has played a very considerable role in history and eroticism can take many forms. On the subject of sexual relations in antiquity, | Vico makes two very important remarks: "Achilles, who cried out so loudly about having Briseis taken from him, and whose anger was enough to fill the Iliad, does not show even once in the whole poem a sentiment of love; Menelaus, who armed all of Greece against Troy to reconquer Helen, does not give, in the course of this long war, the least sign of being tormented by love or of jealousy". 130

The study of eroticism is all the more interesting for social science because this sentiment seems the most to escape political and economic influences: partisans of the doctrine of races do not fail to claim this as evidence that history can be deeply influenced by innate sentiments. For instance, the sensuality of the Semitic races has often been called up as evidence. ${ }^{131}$ Yet it must be said that social conditions exert a considerable influence on eroticism, as Aristotle recognized. He pointed to the enormous influence that women could have on men when the latter are exclusively warriors, as in Sparta. ${ }^{132}$ This investigation into sexual pleasures is far from necessarily leading to what Vico calls, "gallant heroism of the moderns," to which he opposes Homeric manners [moeurs]. A famous passage in Aristotle tells us that the primitive Greeks were always armed and sold their women, which does not indicate very great jealousy among the warriors. ${ }^{133}$ But this question is much too complicated to be treated here.

\section{VIII}

The softening of manners [l'adoucissement des moeurs] described in axiom 67 constitutes one of the most important and difficult questions of social science. Vico returns to it frequently, but he does not succeed in really explaining its process, or the process that leads to this result. Indeed a number of observations suggest that the softening of manners has a great number of causes.

\footnotetext{
130 Book II, chapter 7, §3, p. 491 [§ 708].

131 M. Flach, lesson at the Collège de France, 2o May 1896.

132 Politique, book II, chapter 6, §6 [p. 95. Politics, 50].

133 Politique, book II, chapter 5, §12 [p. 9o. Politics, 48-49].
} 
The cruelty of primitive peoples is first of all connected | to superstition that fills the soul with terror. ${ }^{134}$ Our author observes that this cruelty subsists in more recent times in the mysteries of magicians. He thinks that this is an example of a really constant law because the practice of human sacrifice has existed in all countries, so that it could not have been transmitted between them but must have arisen in a spontaneous way. ${ }^{135}$ The question is certainly more complicated. It can be admitted that terror renders people ferocious; this is a well-established fact, but still difficult to explain;- - as far as the immolation of human victims, this is a practice that could have arisen from different causes in different places. ${ }^{136}$

Magical superstitions do not necessarily contain a religious element, in the proper sense of these terms. Hegel recognized this very well, and today it is broadly admitted that magic contains within itself the germs of science just as much as of religion. ${ }^{137}$ The magician may be ancestor more to the doctor than the priest.

In our own time, superstitions have not disappeared. Far from it. But they no longer exercise so direct and overwhelming an influence on institutions. There are at least two exceptions to notice. I've already spoken about the considerable action produced by fear of epidemics: scientists [savants] too often exploit the terror people feel just as brazenly as African fetish-priests. But those charged with maintaining public hygiene, in almost all the large European countries, try to calm this terror and make use of it. We can follow there a curious evolution. It is understood generally that hygiene involves many superstitions, that archiscientific treatment is not exempt from ridiculous snobbism, but the superstitions and foolishness are differently managed than before. They are used, at least in part, to give us confidence in | provisional improvements that we might have hesitated to adopt after a full critical investigation. In this way, for instance, huge public works have been executed in order to bring water into large cities - even while received theories about the influence of bad water were based at least as much on legend as demonstrable fact. The result was on the whole good, and this is all that can be asked.

\footnotetext{
134 Axiom 40 [§190-191].

135 Book II, chapter 4, p. 438 [ $\S 517]$.

136 Ethnographers have often gone wrong in thinking that a custom [usage] is all the more primitive when we find it more horrible. Vico falls into this error as do many moderns on the subject of cannibalism. M. Flach has shown that cannibalism, when well established, can easily be reconciled with institutional development that is not found in peoples practicing cannibalism in an only intermittent way (Lesson of March 18, 1896).

137 [Hegel] Philosophie de la religion, fr. trans., book II, p. 8o.
} 
Patriotic superstitions seem no less important than the above [medical ones]. They set themselves up against the at least equally strong softening of manners [l' adoucissement des moeurs] by provoking mad terrors. We are especially sensible to fear of treason and this foolishness has led to many crimes. There are few stupidities so great as believing that there could be secret weapons or mysterious formulas. The scientists [savants] who ought to be the first to combat these errors, propagate them in order to prop up their own prestige. It is not too clear to me what of value can come from these superstitions from time to time surging up with a savagery worthy of cannibals. ${ }^{\text {A22 }}$

Vico relates the atrocity of heroic wars to religious ideas: "the vanquished are regarded as men without Gods and lose not only civil liberty, but natural liberty." ${ }^{138}$ This reasoning does not seem able to explain the cruelty of the Middle Ages, any more than the great massacres performed in the philosophical era by the Greeks in their civil wars and by the Romans. In our time, we have seen atrocities worthy of the most distant past return in our civil wars and especially executions done in cold blood, after combat, ordered by men accustomed to civilized life. ${ }^{139}$

The transformation of familial customs is not easy to explain | and its influence is enormous across modern civilization. Vico is not wrong about the early role of woman. He sees her everywhere with the barbarians a slave and thought as a necessary instrument for having children. He attributes the liberation of women to the constitution of the dowry: "it buys liberty from the husband and obtains from him a public declaration that he is unable to support the burden of marriage. This is perhaps the origin of the significant privileges the emperors gave to dowries." ${ }^{\prime 140}$ As an explanation of the dowry, this is more than contestable; but what interests us here is the juridical effect of the contract, not its subjective side. Vico was quite right to connect the importance taken on by women in marriage to a property regime. Failing to take account of the economic side of things has made it difficult to explain the importance of

138 Book II, chapter $6, \S 8$, p. $481[\S 676]$.

139 In colonial wars, the European becomes a barbarian for other reasons. The very strong tendency of the European to imitate the customs [les moeurs] of the barbarians that he is supposedly civilizing is quite well attested. In the first phase of the wars in Africa our officers conducted themselves just as Turkish officers would have. This phenomenon is not so easily explained by well-known psychological theories. The cruelty of the Europeans has to do in part with fear: they are few and riven with fear of being destroyed by their enemies. Their ferocity frees them of dangerous men and augments their prestige.

Book II, chapter 6, p. 481 [§671]. 
women in certain countries. ${ }^{141} \mathrm{M}$. Giraud-Teulon thus associates with problems in the past something that is, often, a juridical development with economic causes.

There are here two really singular opinions on the family:

1) Wills [les testaments] would have been favored by democratic governments in order to divide up fortunes. ${ }^{142}$ However, their effect is often the reverse, and Aristotle objected already to the inconveniences of wills and gifts [donations entre-vifs] in Sparta. ${ }^{143}$ Thanks to the great liberty provided by the law, property was divided up in too disproportionate of a way. It is, anyway, impossible that a liberty can produce anything at all on its own; account must be made of individual sentiments and motives. The will [testament] can lead to very different effects.

2) Vico, observing that in Homer bastards can inherit the throne, thinks that in the time when the Homeric poems were composed, "heroic law had fallen into disuse in Greece, and its place taken by popular law" more favorable to simple blood relations. ${ }^{144}$ It is easy to see that the accession of bastards to political dignity is $\mid$ frequent among primitive peoples. The same things often happened in the Italian tyrannies.

Paternal tenderness is connected to a political and social cause: the cruel education of the heroic era ${ }^{145}$ had been a survival from primitive barbarism, but "when power passed from nobles to the people, plebeians, who took their wealth and power to consist entirely in the multitude of their sons, began to feel paternal tenderness. This sentiment had been unknown to the plebeians who lived alongside the heroes and who raised sons only to see them become slaves of the nobles." $146 \mathrm{~A}$ little later he says, "democracies have goodwill to the sons, monarchies wish that fathers be busied with love of their children," and he thinks that emperors "show themselves favorable to the rights of human nature" because the brilliance of nobility casts them in shadow. These explications will appear to everyone superficial and too artificial.

141 M. Flach, lessons at the Collège de France, 29 April 1896 on the Beni-Amer, according to M. [Werner] Münzinger,-27 May 1896 on Egypt and particularly contracts after the vitth century.

142 Book IV, chapter 5, § 2, p. 586 [§ 994].

143 Politique, Book II, chapter 6, §10 [p. 97. Politics, 51].

144 Book III, chapter 3, p. 525 [\$802].

145 It is not clear why. Nonetheless it is worth remarking that indeed education is almost always behind the manners [moeurs] and institutions of the wider country: corporal punishments have persisted with deplorable cruelty even while social relations have become refined.

146 Book IV, chapter 5, § 2, p. 586 [§ 994]. 
The fact in itself is correct and easy to verify in our contemporary societies: the expansion of democratic ideas leads to a softening of family customs [coutumes]. Aristotle, who lived in a country in which democracy had advanced a good deal, regarded the authority of the father as founded on affection and age. ${ }^{147} \mathrm{He}$ did not see children as beings abandoned to the whim of the head of the family, but as future members of the State, who must be raised in order to take the places of their parents. ${ }^{148}$ Democratic relations are incompatible with rigid paternal power. ${ }^{149}$

According to the Neapolitan philosopher, progress in manners [moeurs] comes from plebeian families. In our own time, we see $\mid$ an analogous phenomenon: relative freedom of family members developed first of all in the middling sections [couches] of the population, in which there was no reason to maintain aristocratic traditions. The upper levels of the Third Estate had imitated the customs [moeurs] of noble families and shaped their ideas about justice according to the habits that they saw above them. Vico tried to show how the legal rules in force between patricians were a model for the Roman plebeians in constituting their own families as property. ${ }^{150}$ We would not say that it is an imitation, but we see there an application of Vico's ideogenetic law, to which we must have recourse in order to understand how ideas are formed and how they are born out of existing forms. The families of commoners in France were transformed when they no longer sought to raise themselves up to the rank of nobility and had lost any reason for considering noble manners [moeurs] as perfect ones. ${ }^{151}$

Today, the proletariat finds itself knocked back and forth between two opposed tendencies. Some of its members try to make themselves bourgeois, and to raise themselves as did the ancestors of the present bourgeois. Others, on the

\footnotetext{
147 Politique, book I, chapter 5, § 2 [Politics, 28].

148 Politique, book I, chapter 5, §11 and book IV, chapter 14, §2 [Politics, 30 and 190].

149 It is probably for this reason that it has been easier to gain recognition for the rights of the child in our contemporary legislation than for the rights of married women. It is understood that there are certain things that cannot be allowed to happen to future citizens and that there are certain obligations to impose on parents regarding their instruction.

$15^{\circ}$ Book II, chapter 6, §1, p. 457 [§598].

151 I find a curious example of what is called the strong manners [moeurs fortes] of the past in the Mémoires de M. Jaume, published by M.Ph. Torreilles in 1894. The author was professor of law at the University of Perpignan: he tells how his grandfather, procurer of the sovereign council of Roussillon, raised with his legitimate children an illegitimate child [enfant adultérin], who he imposed on his wife and who was expelled from the house on the death of the head of the family. This child was entered, under the auspices of his father and with his name, into the order of the procurers (Introduction, p. xiii). Many analogous examples could be found in the old French bourgeoisie. ${ }^{\text {A23 }}$
} 
contrary, full of the feeling of their own class, emancipate themselves from the ideas and prejudices of the higher reaches of society. For proletarians, the conception of the family is quite other than among the nobles and it does not entail paternal authority. It is closer to the peripatetic idea. The division of labor is physiological and engenders sentiments of affection that have no relationship with those that tradition has taught us to consider fundamental. When the proletariat is strong enough, its habits will shape ideas about justice, which will be consecrated in the Code. It is already clear that the free union [union libre] will not fail | to exert a considerable influence on legislation and will transform juridical relations with the family.

Contrary to a generally received opinion, I believe that the constitution of the family (influenced by political life) must be said to be the principle source of our moral ideas. This would be a second ideogenetic law whose importance would be no less great than the one Vico set out. This theory reduces to nothing the pretension of moralists who want to found social reform on individual improvement: this improvement can come only from general causes, forms constituted in daily practice. Vico did not fail to notice the influence of laws regulating family relations, but he does not seem to me to have had a sufficiently broad understanding of their external importance, of their reflection onto all of moral life.

Our century has seen a considerable transformation in penalties. The softening of punishments is a phenomena that seems to take place automatically across the world, but it is not easy to make sense of it, or even to pose the question correctly. Vico is far from having treated the question fully. He does emphasize the brutality of old Roman laws, but he does not follow the changes in modern times. ${ }^{152} \mathrm{He}$ does not speak about the cruel inventions of Italian criminal lawyers during the Renaissance. He says nothing at all about what happens in the law courts of his own time. For causes, he looks to new political forms, but in a confused way. Human judgements "are dictated by a sort of natural shame, respectfor those like us, which accompanies enlightenment. ${ }^{153}$ They [judgments] fit the spirit of openness that characterizes the popular republics ... They fit even better the generous spirit of the monarchs." 154 — "Punishments are made gentler under democracies. The weakness of the multitude renders it more compassionate. Finally, in monarchies, the princes honor themselves with the title of merciful."155

\footnotetext{
$15^{2}$ Book IV, chapter $7, \S 1$, p. 601 [§1020].

153 This is not always seen, when magistrates are not driven by public opinion.

154 Book IV, chapter 4, §1, p. 579 [§974]. This is to say in the human period, after the heroic period.

155 Book IV, chapter $7, \S 1$, p. $602[\S 1022]$.
} 
Many modern authors have denounced the growing gentleness of criminal justice as an aberration of the spirit, and have claimed that this path leads to an indifference about the law, which manifests itself clearly among certain peoples. I would not be surprised if Vico was thinking of his own country in saying that the weakness of the multitude made it compassionate. He indeed lived in a milieu in which popular indifference to the law had grown enormously. In most cases, this compassion provokes ferocious responses: either from the State seeking to shock its subjects out of their torpor by intimidating tortures, or from certain groups organizing lynchings to defend themselves. At bottom, there is no essential difference between the two kinds of reaction: in both cases the goal is to frighten people who live in a criminal way and to defend interests menaced by dangerous groups.

I do not want to enter into the theory of criminology here, since it does not belong in this review. I only want to show how the evolution of punishments can be interpreted and clarified in connection with other concomitant phenomena. This evolution, which Vico describes for us as taking place from barbarism to civilization, repeats itself endlessly in modern history.

There are moments in which a terrified society thinks only of freeing itself from people who trouble its normal life. This is the birth of inexorable laws justified by various theories all founded on social utility. Then, when the terror has passed, there is a period of attenuation, of transformation, when people hesitate to apply rules whose utilitarian meaning appears too clearly and which are opposed to the ruling moral sentiments.

Opposing heroic to human times, Vico observes that primordially the reason of State was supreme law. ${ }^{156}$ Family heads had a direct interest in the conservation of order; their private interest was the same as the public interest. Without this, social ties would have been lacking, and society would have perished. We have seen that this was also a time of ferocious punishments, so we find here an application of the law posed above, according to which the cruelty of punishments is founded on a utilitarian principle.

In human governments, Vico finds "desire for rest, paternal and conjugal 927 love, attachment to life." He observes that | in democracies, power is divided infinitely between all the citizens, that in monarchies, the subjects busy themselves only with their particular affairs. There is no longer the same strong identification of the reason of State with individual ideas [la pensée individuelle]. "This is why men today are naturally brought to consider things according to the most particular circumstances that can compare private interests of equal

$15^{6}$ Book IV, chapter $3, \S 4$, p. $5^{65}$ [§ 950]. 
justice ... The multitude can understand in no other way, because it grasps the motives of justice in their direct application to causes, according to the individual kinds of facts." 157

This requires explanation. The three characteristics of human eras fit perfectly well with countries where juridical indifference reigns and where-in an irregular way-scenes of juridical savagery take place. ${ }^{158}$ Vico does not seem to have taken full advantage of his wonderful observation about the reason of State. The infinite division of political power can have the effect of practically cancelling out this old principle: it falls to the rank of something dormant in consciousness, without apparent effects, - at least in normal times. Each citizen, called on to be judge, puts himself at the same time in the place of the accused. Acts and their consequences are no longer weighed by a master who directs subjects and punishes men who have disobeyed the rules-rather they are considered in the conscience [for intérieur] of each as though they were personal. From this necessarily results a certain indulgence and an attenuation of the social evaluation of the incriminating deed.

So we come to understand why in countries where popular justice exists, things are no longer held up to the sorts of general rules that a jurist, concerned only with reason of State, might pronounce, but are examined one by one and related to the motives that the judge takes seriously according to his own character, his own ways of thinking. As Vico says, the most particular circumstances form the basis for decisions. The functioning of the jury, whose verdicts have nothing to do with rules either in France or in Italy, shows us this clearly.

Civil law is everywhere more or less the business of technicians, | people who have learned formulas. However, the same is not true for penal law. At least in civilized countries each citizen considers it from his own personal point of view, submits all the cases to his own particular ideas, treating it as a dependency of one's self-understanding [conscience-de-soi]. ${ }^{159}$ Many criminal acts (according to the Code or from the point of view of conscience) are intimately bound up with civil interests. Crimes of passion, family dramas, bankruptcies, great frauds, all confront the public with questions of civil law. Through the decisions of juries and open discussion in newspapers, citizens are presented with problems about which they have never learned to think: perhaps they

\footnotetext{
157 Book IV, chapter $3, \S 4$, p. 566 [§ 951].

${ }_{15} 8$ This is why the monarchies, whose mercy Vico lauds, do not seem always to have been very gentle in the 18 th century.

159 It goes without saying that, in many cases, class consciousness predominates here: juries in France, where class feeling exerts a notable influence, take the utilitarian point of view and are quite harsh.
} 
would never even have dared to doubt the perfect wisdom of legislators, if bloody catastrophes or scandals had not posed the problem in a criminal form. This manner of thinking allows us to see legal decisions no longer as a way of acting on the criminal world in order to punish, intimidate, or proscribe. They are, rather, ways of acting on the State [Cité] in order to develop in it new ideas about normal relations and to push it toward juridical perfection. Criminal justice is one of the factors of change in civil legislation; it acts in virtue of Vico's ideogenetic law in order to give birth to moral theories through the practice of public life.

The above explanations show us why democracy really does have a less ferocious idea of punishment than aristocracies dominated by utilitarian considerations. I do not believe that Vico thought about the importance of sentiments developed in a society of equals by participation in criminal justice. Nothing he had before him would have led him to study the problem, which is more interesting for us moderns. He was, in any case, persuaded that inequality was a logical law founded on the distinction of material [matière] and form, of body and soul. "This civil sovereign, considered as a person, has its soul and its body; the soul would be the company of the wise ... the plebeians represent the body. And it is an eternal law of societies that $\mid$ some turn their minds to the work of politics, while others apply their bodies to the arts and professions [arts et métiers]. But it is also a law that the soul must always command, and the body serve." ${ }^{160}$ When the judiciary is drawn from the ruling classes, the so-called wise men who represent the soul of society, its decisions are, in general, very harsh.

A curious characteristic of our contemporary civilization is useful to note: it is not at all the case that atrocious punishments have become impossible, as is too often said. It has only become less possible to admit to them than before, because everyone pretends to act according to democratic principles and the customs [moeurs] that democratic practice has developed. The higher classes always take a utilitarian point of view, but they are less concerned with making examples than with selections: they have therefore adopted a tactic that is not well understood by their adversaries. They want to keep the means of terrible repression, but they do not want this repression to be well known. ${ }^{161}$ While the principle of democratic justice is the identity, in the conscience of each citizen, of the psychological states proper to the judge and the accused,- - the principle of the separation of these states, founded on the real separation of the classes and on the distinctions between master and servile being [être servile],

16o Book II, chapter 6, §5, p. 467 [§630].

161 This is their goal in practicing relegation, transportation, and sending to Algeria those undergoing discipline in the military. 
remains to shape the thinking of our rulers. It is therefore natural that they seek to prevent, on the occasion of punishments, the awakening of sentiments of democratic justice in the popular consciousness that would prevent utilitarian policies from developing fully. Superior men believe themselves to have only a very indirect connection with the lower levels of society, yet they dare not show their real thinking and openly defy popular ideas.

In this summary study of the softening of manners [adoucissement des moeurs], we have twice pointed out the predominant importance of the plebe. Some authors have been struck by this contagion of sentiments that operates from low to high, while imitation ought rather to go the other way ... but they have not sought to offer any other explanation and M. Le Bon limits himself to writing, "the mechanism of contagion is so powerful that its action dissolves even personal interest." 162 But what is this $\mid$ mechanism? This is never explained to us: psychology here fails, as it often does.

However, ideal history also casts a deceptive light. The system of customs [moeurs], which seems to Vico so general and connected in such a simple way to political forms, presents more variety and complexity than he supposes. He maintains tenaciously that paternal power existed in one form everywhere identical to the classical Roman form. ${ }^{163}$ This is simply not defensible. The history of ancient Egypt shows us an opposed and even paradoxical phenomenon: all living beings are placed on the same level and children are not subordinated. ${ }^{164}$ The history of China presents to us a government arrived at the pure monarchical form - the most pure, perhaps, according to Vico's ideas-but in which the ferocity of the criminal code never vanished. ${ }^{165}$ Our philosopher seems not to have known, in any case, this country, for he limits himself to saying of the barbarous regions: "the Khan of Tartary, who united his vast empire with that of China, governs an effeminate people, as were the Seres of the ancients." 166

We see here a new proof of the impossibility of remaining on abstract ground. What must be sought are the conditions of life in the different classes, the history of their conflicts and the ideas that developed over the course of their struggles.

\footnotetext{
162 Psychologie des foules, p. 116. ${ }^{\mathrm{A} 24}$

163 Book II, chapter 4, p. 438, note [ $\S_{517}$ ]. And book II, chapter 6 , $§ 1$, p. 451, note [ $\S 582$ ].

164 Flach, 27 March 1896.

165 According to Vico monarchical government shows itself to be popular, wants its subjects to be equal, busy with their own activities, so that they enjoy "natural liberty" (Book VI, §2, p. 596 [§1008]). See also what has been said above about the familial manners [moeurs] encouraged by monarchies.

166 Book II, chapter 3, p. 628 [§109o].
} 
IX

Historical movement is not one homogenous development. It is not even possible to say, as in physics, that causes have immediate effects. There is a great complexity of changes acting on one another, and one of the $\mid$ most considerable objects of sociology is the study of decelerations and accelerations [in historical change].

Vico understood the importance of these phenomena, and perhaps even on certain points he saw more clearly than modern sociologists, who are too preoccupied with abstract relations. "Each state," he says, "is combined with the previous state, a mixture founded on the axiom: when men change, they keep for some time the impression of their first habits. Patriarchs [pères de famille], having passed from bestial life to human life, keep, in the state of nature, in which there was as yet no government other than that of the gods, their original character of ferocity and barbarism and retain, with the formation of the first aristocracies, the sovereign empire that they had over their children and their women in the state of nature ... The states were at the origin aristocracies mixed with the domestic monarchy of the patriarchs."167

This passage allows us, already, to understand that State forms include survivals, that the State is a retrograde being; but it is not this question, as interesting as it is, to which I want to call attention. The permanence of institutions has to do not only with the psychological axiom enunciated above. This would only give us an insufficient explanation and would not take account of the most important fact, which dominates primitive history, the struggle between groups. Vico is not wrong: he insists strongly on the reciprocal concessions through which the political order is founded. "When the gathering of families formed the first states [cités], the nobles, who had only just left the independence of wild life behind, did not want to submit themselves to the yoke of laws, nor to public duties: here are the aristocracies in which the nobles are lords. Then the plebeians became more numerous and warlike, and the nobles submitted to contributing to public upkeep with the plebeians: here are the nobles in democracies." 168 Contemporary history shows us struggles and

932 transactions in the field of economic law | that recall, in many respects, the ancient history of Rome: when some reform or other is proposed, the upper classes protest against tyranny being inflicted on them and protest in the name of individual liberty that the new law will curtail. Our industrialists are like the

167 Book IV, chapter 6, § 1, p. 593 [§ 1004-1005]. Cf. on continuity, Book II, chapter 6, §5, p. 468 [§631-632].

168 Axiom $96[\S 293]$. 
ancient nobles, they do not want "to allow what they have taken through their courage to be lost through their negligence, but will give way only to necessity or interest, and that only a little at a time and as little as possible." ${ }^{169}$ It is enough to replace courage with merit or talent, and you have transplanted Vico's axiom into contemporary politics.

In the beginning, law was a sort of property of patrician families. ${ }^{170}$ The plebe attacked this property, and demanded enjoyment of rights that the old regime had reserved for nobles alone: these last want to remain masters and to possess unchecked power. "The weak want laws; the strong reject them ... the nobles make knowledge of the laws the secret of their order, so that laws will depend on their whim and so that they can apply the law just as arbitrarily as did the kings ... This is also the reason for the repugnance the senators showed for admitting this legislation: mores patrios servandos; leges ferri non oportere."171 Roman history is only a series of transactions assuring a continuity that made for Rome's greatness. ${ }^{172}$

In axiom 91 [ $§ 281$ ], Vico depicts the situation of the contending parties in the following way: "magnanimous confidence of the plebeians, who want the patricians to extend civil rights to them at the same time as the laws whose mysteries they reserve for themselves; courage of the patricians, who keep within their own order such a precious privilege; wisdom of the jurisconsults who interpret these laws and who extend little by little their usefulness [utilité]. There are the three exclusive distinguishing characteristics of Roman jurisprudence."

From these observations several important consequences can be drawn regarding the problems posed in the contemporary era.

Transactions possess, in all eyes, a $\mid$ more respectable character than imposed decisions. Therefore when reforms are presented to the individual conscience in this form, they do not provoke such a sharp desire for revenge and can rapidly take their place among the intangible institutions. We often see conservatives accept rather easily laws made against them and then not even want to hear about a return to the past when they again have power: modern industrial life is so intense that any innovation may link itself very quickly to a mass of interests so that it can become more difficult to get rid of than it was to introduce.

\footnotetext{
169 Axiom 82 [In fact, 81. §261].

170 Book IV, chapter $5, \S 2$, p. 588 [§998].

171 Axiom 92 ["the customs of the fathers must be preserved ... the laws must not be published". § 283-284].

172 Book IV, chapter $5, \S 3$, p. 592 [§1003].
} 
All transactions suppose that there had previously existed a dubious region of the law, a precarious situation justified by old habits, but destined to disappear when new circumstances arise to show its confusions. Reform takes place in this region, and the wisdom of legal scholars is supposed to limit the movement, in order to avoid stepping beyond what might be called the threshold of possible agreement. While things remain on this middle ground, the movement has in the mind of the jurist a progressive character: the old situation corresponding to vulgar wisdom, to the order of things founded only on unreasoned custom [usages], to the practicality of a vulgar empiricism; - the new situation having been introduced by discussion and comparison, demonstrates the desirable reaction of reflective thought on historical material. This way of thinking about phenomena plays a capital role in modern history: indeed, psychological evolutions of this kind are irreversible, as Vico recognized. As long as we have the feeling that a juridical transformation has been accomplished in the natural order of psychology, we do not feel the desire to revolt and to return to the past. The reform becomes inviolable, because it appears with that particular tone of sentiment that corresponds to the vulgar notion of progress. ${ }^{173}$

History does not always show transformations made in this transactional way. Vico is not so taken in by the sophism of ideal history that he does not see that Rome is exceptional in this regard. Many times, attempts were made to exceed the limits of the dubious region of law in order to establish a new regime by force. This operation can succeed only if the vanquished entirely disappear. And it has succeeded more than once, as the history of religious persecutions shows us. Civil wars are so ferocious because they have for object exactly the transformation of institutions through violence and the destruction of adver-

173 These considerations cast new light on the conception of progress: the men of the 18th century were not completely wrong in assigning such great importance to the progress of enlightenment. They translated (incorrectly, it is true) the psychological process [processus], much better understood by Vico than by them and definitively elucidated by modern science, which makes us pass continuously from a less to a more intellectualized state. Vico's error was to not see that the passage does not take place in a bloc and that it is renewed constantly from the affective bases [ $\$ 934]$ of psychological evolutions: this point cannot be too much insisted upon.

Against Bodin, Vico maintained that aristocracy cannot succeed the popular state, nor royal government. This would be "irreconcilable with the social nature of man." On the other hand, monarchy and the popular state can permutate (bookv, chapter 2, p. 625, note [ $§ 1087])$. We see here an application of two psychological principles: 1 ) the irreversibility of psychological evolutions; 2 ) the substitution of equivalents. I called attention to one of these substitutions in an earlier article (February 1896, p. 126, note) ${ }^{\mathbf{A 2 5}}$; these substitutions can take place only on the basis of a profound common sentiment, as is easily seen in the case I examined. 
saries. In their wars of conquest, the Romans were so easily able to impose their customs [moeurs], their laws, their language, because their great preoccupation was to eliminate the old ruling classes which might have kept too vivid a memory of the old culture.

It has often been objected to socialists that the proletarian revolution will be obliged to follow the same law, that it must take on the ferocious character of a war of extermination, and that it will compromise a European civilization acquired with such patient labor. This reproach would be well founded if the proletariat was an exalted mass, maddened by idealist preaching, ${ }^{174}$ baying for the destruction of worldly things and breaking abruptly with the past under the false pretext $\mid$ of realizing a marvelous plan worked out in some big brain or other. But this is not how it will be, because the first condition of the future revolution is the development in the proletariat of the consciousness of its historical role; the second condition is that the organization of labor by large industry be so adapted to the needs and conditions of collective production that economic realities constitute the bridge by which the passage from one state to another will take place;--finally, social hierarchies must be no more than shadows.

Juridical continuity will not even be violently broken by the proletarian revolution, if contemporary civilization has elaborated a system of laws prudently regulating the relations between industrialists: the capitalist part of the Codes can disappear, as the feudal regime disappeared, without much troubling juridical ideas. It is therefore of the greatest importance for socialists to accelerate the movement of juridical reforms and to take what they can get, even if the new laws leave much to be desired.

Socialists often meet with the objection that their conception of total revolution is in opposition to the laws of history, because the most apparent character of all existing transformations is the transaction. Marx was perfectly familiar with this objection and he did not hide what was new in the idea of revolution whose theory he was sketching, but he showed also that the proletarian forces developed by large industry were not insufficient to overcome the capitalist order. The transaction is the necessary character of two active minorities fighting for their share, it assures continuity by bringing the newcomers into

174 I do not say led by the idealists, because these gentlemen lead nothing: they content themselves with confusing the people's reasoning with their illusions, their promises, their demands; and when enthusiasm has rendered men incapable of reasoning, they wash their hands of the spilled blood and speak about the purity of their intentions. It is unlikely that an idealist revolution will not be bloody. We others are for a revolution founded on knowledge of the possible, and such a transformation can hardly include proscriptions. 
the civilization of the old possessors of the law. But if the proletariat becomes, in industry, the only living organization, if there remains alongside it only a powerless and negligible minority, if it eliminates from within itself any form of hierarchy likely to separate itself out and form a governing faction, if finally the development of social legislation has invested it fully with the idea of law:economic and juridical continuity will be assured without a transaction. We can even add, in reference to the theory of civil wars mentioned above, that the greatest revolution the mind can imagine will be the most peaceful,--because it will not find before it any adversary that might be reborn.

936 When one examines history from the objective point of view-which is | ours,- - one no longer has any interest in pontificating on the moral motives that have inspired men. One no longer pretends to judge ancient institutions according to some ethical norm or other. The philosophical historian no longer thinks of himself as the director of the people's conscience. One simply tries to understand [savoir] what role certain social rules have played in the passages from one form to another. All readers of Capital know that this is Karl Marx's way of proceeding and it seems to me useless to bring in citations on this subject. Vico also asked himself what results had come from vanished institutions and he understood them as preparation for subsequent institutions. Thus, for example, he maintained against Plutarch the usefulness of barbarian religions, which served as a first step toward civilization. ${ }^{175} \mathrm{He}$ said, speaking of the first, ferocious families, "men, having left their native liberty and [been] tamed by the severity of family government found themselves ready to obey the laws of civil government that would succeed it."176

In Vico, this theory of preparation is subordinated, as always, to providential wisdom and, therefore, bound tightly to moral and religious valuations. Evidently modern science can undertake to dissociate these without the least difficulty and conserve the historical theory without keeping the theory of Providence. It is useless to insist on this.

The causes of historical movement are not abstractions or logical considerations. ${ }^{177}$ The presocialists gave themselves | a great deal of trouble trying to show that not everything was perfect in the world and they finally decided

\footnotetext{
175 Book II, chapter 4, p. $439[\S 518]$.

176 Book II, chapter 5, §1, p. 441 [ $\$ 523]$.

177 Here again I return to M. Jaurès' theory about contradictions provoking revolutions. He borrows from Spinoza this idea that all tyranny must disappear by virtue of the forces it has itself provoked: if it is too hard, it provokes desperate insurrection, if it is gentle, it prepares men for liberty (Idealisme de l'histoire, p. 23). It would not be useless to reread the last chapters of Aristotle's Politics where so many revolutions are recounted: it will be seen that in antiquity, things did not happen so simply. And now that we know better the
} 
on the extirpation of everything that seemed to them to engender contradictions. ${ }^{178}$ It would have been just as worthwhile to resolve on destroying humanity, because this is to pronounce an end to any development.

History is continuously presenting to us decisive figures, whose character, tendencies, and genius, must be the object of special study. Vico sought to trace a general picture embracing all the essential elements of this political psychology. "First we see coarse and barbarous figures rise up, like Homer's Polyphemus. Then come the proud and magnanimous such as Achilles. Then the just and valiant, Aristides, Scipio. Later on there appear, with noble images of virtue and at the same time great vices, those who the vulgar judge to be truly glorious. Later on there are the somber characters, of thoughtful [réfléchie] malice, Tiberius. Finally come the mad who abandon themselves to shameless dissolution, like Caligula, Nero, Domitian. The hardness of the first was necessary in order that man, obeying man within the familial state [état de famille], would be prepared to obey laws; - the second, unable to cede to their equals, serve to establish after the familial state aristocratic republics; the third, to open the path to democracy; the fourth to raise up monarchies; the fifth to weaken them; the sixth to overthrow them."179

I have quoted this long extract in order to show clearly how consideration of ideal history confuses the questions. The characters are arranged in an empirical order, without any link appearing between then, and their role is not always the same in the order of events. The regularity, uniform connection of cause and effect, everything that might give a scientific value to the exposition, is missing. The historian cannot say what produces a Caesar at a given moment, but he can try to know what causes make a Caesar decisive in given circumstances.

In another passage, Vico seeks to pose principles of $\mid$ a quite different order. He examines the goals pursued by the active parties of classes engaged in struggle and the situation of people in each of the considered cases. "Men love, first of all, to free themselves from subjection and desire equality; - thus the plebeians in aristocratic republics, who finally made popular governments. They seek next to surpass their equals; - thus the common people in popular states

great Asiatic monarchies, what can we think of this so-called demonstration of Spinoza's? Aristotle already knew very well that things did not happen among the barbarians as they did with the Greeks, among whom there were a great many causes, deriving from true sentiments and not theoretical sentiments of abstract man, fabricated for the needs of contemporary sociology.

178 Catholic writers continue to engage in this sort of discussion, which is entirely without interest since Marx placed socialism on a scientific basis.

179 Axiom $68\left[\S 243^{-244}\right]$. 
that degenerate into oligarchies. They want then to put themselves above law and from this results unbridled democracy ... Then the common people seek a remedy and flee into monarchy."180 The nobility also accepts this solution, seeing in it a guarantee of rest and the possibility of leading an easy life. ${ }^{181}$

I will not stop to criticize the inexactitude of this picture, which is too broad. But I think it is useful to briefly signal here one important particularity. Active groups, which form the army of revolutions, are moved by considerations that are not at all the same as those found in the first rank of decisive men. These latter are strongly individual, and their individual sentiments play a capital role, but in groups very different sorts of sentiments develop, or more exactly individual sentiments take on a different kind of color. It is these affective group tones that the historian ought above all try to bring to light, and that Fr. Engels signals as susceptible of entirely objective study. ${ }^{182}$

These affective group tones express themselves in demands and, for this reason, they have often been confused with juridical idealities. Thus the search for equality that Vico pointed to as a motor of revolution is confounded with a metaphysical theory of equal rights, and so on. We touch here one of the causes that have lead idealists so badly astray in their historical interpretation.

This error is all the easier to make because revolutions rarely fail to work some profound transformation in the juridical characteristics of society. It is imagined that the motives of the actors in the drama were all dictated by a clear view of the result obtained, and their conduct is judged by that to which 939 a theoretical man ought to have held in pursuing this goal. |

All revolutions fall into two distinct types: the struggle can have as object the exploitation of public power [force], or it can try to change the situation of the classes. Vico knew perfect well to distinguish these two cases: the first seemed to him to belong to the decadence of popular states and to the period that prepared monarchy, the second alone was productive. The struggles between rich and poor in the Greek republics represented the first time, those of the plebeians against patricians the second. In reality the two types are almost always mixed in history. One of the great difficulties experienced by contemporary socialism consists in acquiring a clear idea of the proletarian revolution, in fully understanding what distinguishes it from a war of the poor against the rich and in shedding the superstition of the State. ${ }^{183}$

\footnotetext{
180 Axiom 95 [§292].

181 Axiom $96[\S 293]$.

182 Cf. the passage already cited in § IV.

183 Also, one popular school seeks to oppose the progress of socialism in the following way: to divide the proletariat and bring out the most active minorities to which exceptional
} 
Connected to these problems is a very obscure question, on which we have thus far only incomplete studies, I mean survivals [survivances]. Regarding the survival of Hellenic fables, Vico's observations seem to me to have a considerable value, although he was unable to resolve all the difficulties. "They were at their origin true histories of a serious character. The fables were born bizarre and became successively less appropriate to their original subject, changed, untruthful, obscure, with a shocking and finally incredible effect." 184 The philosophical era gave them interpretations without any relations to their historical origins, but they nonetheless continued to play a considerable role in the development of thought. Here is how Vico explains the phenomenon. The fables gave philosophers, "an easy way to present the most sublime ideas by using the expressions of poets, a beneficial heritage that they had | received;- - ease of consecrating their opinions with the authority of poetic wisdom and the sanction of religion."185

I do not know that this last consideration is of great value, since it is unlikely that religion had played at the origin of societies the preponderant role attributed to it by our author. We know that a great number of tales or practices of the most profane origin became dogmatic expositions and rites at a late date in history. This is hardly contested for the history of the Israelites: it is hard to believe that a religious sense had been attached to many of the Jewish legends. The celebration of Easter and the rite of circumcision do not appear to have had religious origins. In general, a custom [usage] whose original meaning is lost, but which continues to maintain itself in a state of solemnity, takes on a ritual character and gathers around itself a rich literature of legends: the causes of this paradoxical phenomena remain to be given.

Whatever theory one uses to explain primitive practices, the respect that the Greeks had for their fables cannot be denied. Many of them, those that had passed through the hands of the great poets, possessed aesthetic prestige. Finally the national poems and songs, having served for the education of the youth, evoked in affective memory a great many emotional tendencies. In introducing into their discourses [exposé] many well-known fragments, philosophers transported to their works a part of the sentiments that these fragments

advantages will be granted; - to demand great monetary sacrifices from the rich in order to show the poor the devotion of the upper classes; to reorganize the whole State in order to give more satisfaction to ambitious members of the poorer classes. Cf: Aristotle's reflections on how to preserve oligarchies (Politique, Book vinI, chapter 7) [Politics, 134139]. These efforts cannot be successful because proletarian socialism proposes something quite other than simply sharing wealth and honor. ${ }^{\mathbf{A 2 6}}$

184 Book III, chapter 5, p. 531 [ $\$ 814]$.

185 Book II, chapter 1, § 1, p. $375[\S 362]$. 
had evoked. It is really essential for an innovator to find a way to develop for himself the sympathies of his readers: no philosophical system has owed its success entirely to the logical value of its arguments. It has always been necessary for the author to find a way to provoke emotions that will tip the balance of our spirit in his direction. No doubt faith seeks to justify itself before reason, but the justifying reasons would have no value if there did not exist profound affective states giving consistency to the beginning of belief. ${ }^{186}$

The same can be said of all philosophical theories. It must be observed also that these affective means act all the more effectively the less our mind is on 941 guard, and everything takes place in $\mid$ a domain that escapes apperception. We see here the importance of survivals: in citing fragments of respected poems, the Greek philosophers did not present their doctrines as consequences of the fables from which these expressions were borrowed-reason would have revolted against such a system - they only provoked subconscious states [états ignorés de la conscience], waking affective memories through simple signals. ${ }^{187}$

Vico goes even further. He understood very well that the innovator experiences the greatest difficulty in presenting revolutionary ideas in a language that has been adapted to other systems. Over language, the public has as it is said a sovereign power and everyone is obliged to understand things as do the mass of people. ${ }^{188}$ One must therefore speak a new language and experience shows that there is no language richer in new forms than that into which have been mixed ancient expressions that have lost their earlier meaning. The history of early Christianity is a good illustration of this principle. In making use of expressions borrowed almost entirely from books familiar to the Jews, Saint Paul succeeded in constituting a theology that was in absolute opposition not only with the historical meaning of these books, but also with the interpretations that the rabbinical schools had made familiar to their listeners. ${ }^{189}$ No doubt this is an extraordinary example, but many less striking examples of this procedure exist. The Reformation followed Paul's methods with great success and set new ideas in what was apparently a very ancient language. We know that attempts in this direction were made by the presocialists, but failed. The sentiment of historical truth is today too well developed for exegetical inter-

186 Read on this subject chapter three of the third book of Croyance by M.J. Payot.

187 Detached from their origin, these fragments became simple poetical abstractions and thus are ruled by the well-known law of the permanence of abstracts; everything we learned in childhood maintains itself in this way and acts on us without our knowing.

188 Book IV, chap. 2, § 2, p. 559 [ $\$ 936]$.

189 No one, in any case, worried about historical meaning. Saint Paul was less daring than were the Jewish doctors of the Talmudic tradition. ${ }^{A 27}$ 
ventions to have much chance of succeeding. Socialism must therefore follow a purely scientific path, as difficult as the scientific road sometimes can be.

Study on Vico ${ }^{190}$

(end)

$\mathbf{X}$

Vico's attempts to determine the laws of expression of human ideas are of great interest. At the time he wrote, science was yet in possession of too few pieces of the puzzle; his etymologies are generally very arbitrary and imposed rather than demonstrated. Michelet has eliminated many of these overly bold interpretations, but more than enough remain. It seems to me tiresome to insist on this.

In order to fully understand Vico's thinking and to realize its full value, it is not useless to recall the principles of scholastic philosophy regarding understanding and language. M. Mercier, the professor from Louvain, begins his theory of ideas by posing this proposition: "Intelligence has for its proper object only material things;" and among the proofs that he gives is this, drawn from language: "in following up the etymologies of higher ideas, such as the ideas of being, understanding, thought, intelligence, wisdom, those of virtue, relation, duty, right, justice, finally those of soul, spirit, God, one arrives always at notions whose meaning is entirely material." ${ }^{191} \mathrm{He}$ says further, "the proper object [of intelligence] is material objects; its improper or indirect object is immaterial beings, the human soul, minds, God."192

It is therefore very easy to understand how Vico has written: "We see in all the languages things belonging to the soul and to the intelligence expressed in metaphors which are drawn from bodies and their properties." ${ }^{193}$ This proposition would have been rather difficult to demonstrate, but it must have seemed to him evident because it conformed with traditional doctrines. His affirmation did not present itself with the paradoxical character that has been attributed to it on occasion in our own times.

The difficulty begins in trying to pass from these very general conceptions to historical applications. Axioms 17 and 18 [ $\$ 11^{1-153]}$ are quite vague: "Vul-

\footnotetext{
190 See the November number.

191 [Mercier] Psychologie, p. 293.

192 Op. cit., p. 288.

193 Axiom 63 [§237].
} 
gar ways of speaking [parler] are the most serious witnesses to national habits [usages] in the times when languages [langues] were formed. An old language that has remained in use ought, considered before its maturity, to be a great monument from the first ages of the world." But how to reason confidently about such old texts? A curious attempt has been made in recent years to interpret the Vedas according to a system analogous to what Vico proposes. M.P. Regnaud observed that words to which tradition attached a religious meaning must have had a material meaning that could be recovered. So he transformed the hymns by translating them with a dictionary made in this way. The attempt seemed to him more all the more defensible as orientalists are obliged to hazard hypotheses to arrive at meanings for many expressions that have fallen out of the language of the Hindu commentators. Regnaud's results seem generally paradoxical and have not been accepted by orientalists.

Vico seeks, as is his habit, to determine the different moments of the process in axioms 64 and 65 [ $\$ 238-240$ ]: "The order of ideas must follow the order of things.-Such is the order that human things follow: first the forests, then the huts, then the villages, next the cities [cités] or reunions of citizens, finally the academies or reunions of the learned [savants]. The history of indigenous [indigenes] languages must follow this series of changes undergone by things. Thus, in the Latin language, we can see that all words have wild and rustic origins."

This last observation derives naturally from the principles posed earlier: primitive words could not have come $\mid$ at first except from the vocabulary of peasants. But it is remarkable that Vico considers languages as having been subordinated to academies in eras of full civilization even though he says, so often, that the people is absolute master of the meaning of words. ${ }^{194}$

Vico supposes that originally men did not speak. "Divine language was hardly articulated and almost entirely mute; the language of Heroes mute and articulated in equal measure; the language of men mute almost not at all and more or less entirely articulated." ${ }^{195}$ But what could this unarticulated language be? We must, to follow Vico's principles, try to see what use it was, how it was connected to the intellectual development of barbarous men; - the diversity of languages, ${ }^{196}$ like the diversity of customs [usages] is, indeed, caused by the variety of aspects under which one sees the things that are useful or necessary for life. It is not the things themselves that man wants to indicate. This consideration belongs only to periods of higher development. At the beginning, man put himself only in a very summary relation to the world and he saw it

194 Book IV, chapter 3, § 5, p. 568 [ 953] and book II, chapter 3, § 4, p. 416 [ $\$ 439]$.

195 Book II, chapter 3, §4, p. 419 [ $\$ 446]$.

196 Book II, chapter 3 , § 4, p. 418 [§ 445]. 
only through his impassioned nature, "at that time he was a stranger to any abstraction, any subtlety, dulled by the passions, plunged into the senses and, as it were, buried in the material [matière]." ${ }^{197}$ From this it results that the first expressions of language were connected to emotions.

Vico has perhaps not done all that he could have with this theory. He makes several ingenious remarks. "The first men must not have tried to speak until they experienced extremely violent passions. Such passions are expressed at the top of the voice, which multiplies diphthongs and becomes a sort of song. This first song came naturally out of the difficulty of pronunciation." ${ }^{198} \mathrm{He}$ rests this doctrine on several quite faulty observations: he says that people who stammer stop on syllables that are the $\mid$ easiest for them to pronounce and in this way make a kind of song,- that the ancient "Greek and Latin prosewriters made use of poetic quantities, - [ that in] the Middle Ages the Fathers of the Latin Church did as well, and [that] their prose seemed made to be sung." ${ }^{199}$

It is not out of place to ask what after all Vico means here by song: does he mean to speak of rhythm only, or of melody? It seems quite likely that rhythm played, indeed, a very considerable role in the consolidation of the first emotional expressions; the primitive sonic gesture (Klanggeberde) is much less related to the representation of things than pantomime and it is not easy to understand how it could become fixed and give birth to articulated language through its own principles.

It is not plausible that language [le langage] was used at first for the simple purposes it fulfills today: it is a very exceptional way of expressing one's self. Our philosopher indicates the oracles of the Sibyls, sung in heroic verses, as one of the first forms of language. ${ }^{200} \mathrm{He}$ develops at length the idea that old Roman law [droit] was a serious poem and he attaches great importance to the expression carmina, used to designate the ancient juridical formulas that were to be fixed in an invariable way. ${ }^{201}$ In the times that preceded articulated language, men experienced the need to have signs to constitute solemn affirmations, to determine the certain: one made use then of acts of the body, a

\footnotetext{
197 Book II, chapter 2 , $§ 1$, p. 386 [ $§ 378]$. He says elsewhere: "the first men were almost as entirely incapable of generalizations as the animals, for whom all new sensation entirely erases the analogous sensation that they could experience; they cannot combine and discuss ideas." (Book II, chapter $7, \S 1$, p. 487, note [§703]).

198 Book III, chapter 3, §5, p. $424[\S 462]$.

$199[\S 462]$

200 Book II, chapter $3, \S 5$, p. 426 [ $\$ 463-464]$.

201 Book IV, chapter $7, \S 2$, p. $6 \circ 8$ [§1037].
} 
well-rhythmed mimicry, what might be called a juridical dance. ${ }^{202}$ Later on verbal formulas, just as rigorously determined as the earlier movements, served. It therefore seems quite reasonable that gestures of the body and gestures of sound were submitted to the same evolution and that they were fixed in the same way, through rhythm. The hypothesis of a primitive song, either in oracular consultations or in juridical constitutions, is therefore very natural.

And there is another fertile idea to be found in Vico, which is that one must not separate the history of languages [langues] from that of letters (or rather of signs that have served to express ideas graphically). ${ }^{203} \mathrm{He} \mid$ says, "the first nations thought by means of symbols or poetic characters, spoke using fables as signs, wrote in hieroglyphs." ${ }^{204}$ It must be understood that originally [à l'origine], the goal was not to express a thing, but to recall actions.

Vico is right to indicate as the primitive forms of language "the five material words that the king of the Scythians sent to Darius, son of Hystaspes, the poppies that Tarquin the Proud beheaded with his scepter before his son's messenger." 205 When M. Schweinfurth passed into the land of the Niams-Niams, he found tied up to a tree a blade of grass [un épi], a rooster feather, and an arrow: this constituted an inscription whose meaning he did not mistake for an instant. Here it is clear that each object recalled a complete action and no doubt was possible because each of the objects can evoke only a few sentiments in the simple mind of the savages. The meaning is determined by the affective states that a sign can call forth. The Scythian's message was more complicated, and Darius did not understand it, he was already intellectualized, while that [the sign] of the Niams-Niams appealed only to affective memory. ${ }^{206}$

Juridical signs still play here a great role and Vico highlights them among the elements that have served to form language [langage]. "The first pagan nations expressed themselves through gestures or materials signs, which had a relation with ideas; they had to affirm through signs the limits of their fields and con-

\footnotetext{
202 Book IV, chapter 7, §2, p. 611 [§1045].

203 Book II, chapter 3, §4, p. 408 [§ 429].

204 He says elsewhere that Varro brought together the names of thirty thousand gods; it was the vocabulary by means of which "the nations of Latium were able to express the needs of human life." These names were so many because each fountain and each rock had its fable. "The divine fables of the Greeks and the Latins were for them the first hieroglyphs, the sacred characters of this divine language." (Book II, chapter 3, §4, p. 414 [§ 437]).

205 Book II, chapter $3, \S 4$, p. 414 [ $\$ 435]$. We can remember here as well the pantomimes in which the Hebrew prophets engaged.

206 Observation made by M. Flach in his lesson of 25 March 1896. (Cours du Collège de France).
} 
serve durable monuments of their laws; ${ }^{207}$ all used | coins. ${ }^{208}$ All the truths that we have just set down give us the origin of languages and of letters, in which is included that of hieroglyphs, of laws, of names, of heraldry, of medals, of coins, and in general of the language and the writing in which, in its origin, the natural right of peoples was spoken and written." 209

If today it seems somewhat paradoxical to many people to attribute such a large place in the history of languages [langues] to very primitive law (and to the oracle, which is hardly detached from it), an important idea of Aristotle's must be remembered, "the voice can express joy and pain, and it is not absent from the animals ... But speech [la parole] is made to express good and evil and, in consequence, the just and the unjust; and man is special in this way, among all the animals, that he conceives of the good and the evil, the just and the unjust, and all the sentiments of the same order that, in association with one another, constitute the family and the State."210

If this is so, language must be considered to have as object not the things in themselves, but much rather certain particularly human relations relative to the use of things. According to the Stagirite, ethics is that which is most human, and on this point Vico does not seem to disagree. It is therefore natural to seek the strongest and most living causes in juridical relations. This does not prevent us from thinking that language [langage] may form itself at least partially by means of other elements from the artificial milieu; but it is reasonable to attend first of all to which is most specially human.

The Neapolitan philosopher tries to go further and to determine the order in which the grammatical forms were formed: interjection, pronouns, particles and prepositions, nouns and verbs. I want to point out here Vico's singularly psychological reasoning: "We can observe that children say nouns [les noms], particles, and not verbs: it is because names [les noms] give rise to ideas which leave durable traces; it is the same for particles that signify modifications. | But verbs signify movements accompanied by ideas of anteriority and posteriority and these ideas cannot be comprehended except with the indivisible point of the present, so difficult to understand ... There exists here a man who, following an attack of apoplexy, remembers perfectly well nouns [les noms], but has

207 The importance of signs in the formation of juridical ideas and particularly in the evolution of the idea of property in land, is often indicated by M. Flach. On occasion, it is possible to penetrate up to the point where the sign [1018] still has all its material value, its signification as object having had utility (for example, the enclosure in plants that conserves the footpath with the Mongoutous: lesson of 25 March 1896).

208 There is a nice example of ideal and reasoned history!

209 Book II, chapter 3, §4, p. 412 [§ 434].

210 Politique, book I, chapter 1, §10. 
entirely forgotten verbs." 211 In this case, as in many others, Vico totally abandons the method of historical induction.

There is no analogy to be established between the infant who learns to speak under the influence of his parents and the savage who had to form his language [son langage] in the midst of the events of a quite complicated existence. ${ }^{212}$ As far as the order in which an ill person loses words of different sorts, this order has no relation with the order in which languages [langues] were formed. According to M. Wundt, in any case, verbs in general persist longer than "words which are connected to concrete sensorial representations."

Here is another singular theory: all primitive peoples represent the gods and heroes with superhuman proportions. In the Middle Ages "the figure of the Father, of Jesus Christ and of the Virgin [are] of colossal size." Vico finds a singular sort of reason: "It is proper to barbarians always to enlarge and extend particular ideas. [...] The reason must be that the human spirit, infinite in its nature, yet constrained by the crudity of the senses [des sens], could not exercise its almost-divine faculties except by extending particular ideas through the imagination. It is perhaps for this reason etc."213 It seems simpler to think that the authors of ancient drawings wanted to represent forces as they conceived them, and not make portraits in the modern sense of the word. In general primitives do not concern themselves at all about resemblance, perspective, the coordination of forms: they put into subjective order everything that strikes them. Royal personages, having | much more power than their subjects, are represented as taller: the moderns, much more objective, want a reasoned and quasi-scientific shape; the barbarians want to translate all their impressions in a clear way and worry little about science.

Vico rightly observes that children and barbarians speak in very general terms. This seems all the more natural because their language does not try to seize hold of the objective character of a particular being, but to recall impressions, affective states. When thought begins to develop itself, it must make use of this verbal material that has not been prepared for it, and then ambivalence and incoherence begins. Reasoning must proceed by drawing things into kinds [genres], but kinds that have as yet nothing scientific about them. "Without

\footnotetext{
211 Book II, chapter 3, § 4, p. 420[-421. § 454].

212 M. Wundt says: "mothers and nurses are the inventors of the child's language." Visual memory plays a very great role in education: thus the considerable importance of substantives, which do not have the same meaning as for primitives: they connect to each name a certain group of actions. In our civilized language the substantive is still used very often to designate not this or that, but rather the nature of one thing or rather even of a class of things. It is quite otherwise for the child, who joins together sound and vision. ${ }^{\mathbf{A 2 8}}$

213 Book III, chapter 5, p. $532[\S 816]$.
} 
kinds there would be no ambivalences, I do not know, in truth, if the kinds have not been the cause of as many errors for philosophers as the senses have been for the vulgar of false opinions and prejudices. The kinds confuse ideas as much as prejudices obscure them." 214

We find here described in a very clear way the doctrine that will guide in our own time a quite significant school of research in mythological interpretations.

\section{XI}

The great difficulties experienced in study of ancient civilizations come from knowing relatively little about the functioning of this logic of imagination, which then held the place of the logic of the philosopher. And yet there are many points at which such study can be undertaken and Vico has more than once illuminated these difficult questions.

All this research is dominated by a general principle, of which M. Flach made the greatest use in his course at the Collège de France and which Vico developed in several ways: primitive peoples do not understand the subtleties of our reflective thought; figures, images, fictions, hardly exist for them; everything has the same degree of reality. It is impossible for them to separate the thing and its simulacrum.

Originally, following Vico, "Jupiter, Cybele, Neptune, were simply the sky, 1021 the earth, the sea, that the first men, still mute, expressed by indicating them with their finger. With the names of these three divinities, they expressed all things relative to the sky, to the earth, to the sea. It was the same with the other gods. They connected all flowers to Flora, all fruits to Pomona." ${ }^{215}$ It should be remembered here that it is not the things themselves that are designated, but actions that are related to the sky, the earth, the sea, and so on. It is indeed much easier to understand that one could bring under the same sign similar actions than beings whose appearance is so different. ${ }^{216}$ Vico frequently insists on what he calls the principle of uniformity, in virtue of which the same personage received the attributes of those that have some resemblance with it, but he does not distinguish sufficiently the different meanings that this principle could have.

\footnotetext{
214 De l'antique sagesse de l'Italie, chapter II, §4, p. 233 [Most Ancient Wisdom, 62].

215 Book II, chapter $3, \S 1$, p. 397 [§ 402].

216 This is why a change in physiognomy appeared to them a new face, a new passion indicated a new heart (Book II, chapter $7, \S 1$, p. 487 [§700]).
} 
In axiom 47 [ $§ 205]$, Vico observes that the vulgar attribute to famous men adventures related to their character. ${ }^{217}$ We are here in the presence of a principle of imaginative logic, which can find daily application. It is the character, it is the way of acting, that forms the principle of agglutination in fables. It is clear that this work can be undertaken only in brains of an already human development and that children can give us no indication about this kind of intellectual work, even though our author does not fail to invoke their example in axiom $48[\S 206]$.

Elsewhere, Vico expresses the opinion that, even in historical eras, laws have been attributed to legislators-Solon, Lycurgus - the honor of which could not possibly have been theirs. "Perhaps Solon is only the people of Athens, considered as recognizing its rights, as founding democracy. The Egyptians had attributed to Hermes all useful discoveries, the Athenians attributed to Solon all democratic institutions." 218 The same observations are then presented for the first kings of Rome.

Commenting on axiom 49, he makes his thinking more precise: "The Egyptians attributed all useful discoveries to the type of the wise man in matters of social life; and as they could not arrive at this level of abstraction, and still less that of social wisdom, they personified the whole kind under the name of Hermes." ${ }^{219}$ Thus it really is a large category of relations existing in the milieu that form a kind and that receives a single unique sign. It is not things that are assimilated, but actions.

The imagination possesses the faculty of abstraction, but it abstracts in its way, choosing from a vast picture [tableau] the marks that suit it to recall the ensemble of relations that the totality evoked in a more primitive way. "These vast imaginations," Vico says, "curled themselves up and were indicated by the smallest signs. Jupiter, Neptune, Cybele, became so small and so light that the first flew on the wings of an eagle, the second rode on the sea, carried in a thin shell, and the third was seated on a lion." 220 But each of these signs was, just as much as the things that it replaced, the bearer of all the relations, and these relations could not be separated from the sign.

\footnotetext{
217 This axiom is placed at the head of those that are related to poetics, those that treat uniformity are numbered 48 and 49 [ $\$ 206-210]$.

218 Book II, chapter 3, §3, p. 404 [§ 414].

219 [§209]

220 [p. 398, §402. Bergin \& Fisch give this sentence after "signs": "Metonymy erected into dogma the prevailing ignorance of these origins of human things, which have remained buried until now," but it does not appear in Michelet].
} 
This impossibility in which vulgar thought finds itself of making the separation is seen as well in all the poetry that piles onto a figure qualities that it had not had. "These lies of fact are truths of the idea. The true captain, for example, is Tasso's Godfrey, all those that do not conform to this model do not merit the name of captain." ${ }^{221}$ It cannot be said that this is a law proper only to primitive peoples and to children: it is rather a general law of our creative imagination across time.

The cult of icons presents to us the same principle in action in religious life. And it should be repeated tirelessly that religious life offers to the observer the most easily studied psychological phenomena. Has it not often been asked why one image was more venerated in a particular circumstance, or by a given group, than any other representation of the same figure? This differentiation seems absurd to one who takes the point of view of reflective and calculating reason. But reason provokes affective states much more than purely intellectual $\mid$ ones. The imagination obeys, always, the same laws. The Madonna is one unique entity, but the worshiper is not moved by simply theological considerations; if he addresses himself to an icon, it is because this figure recalls for him a group of memories, each possesses its miraculous legend, evoked by the plastic sign. To adore a particular Madonna is therefore to evoke all the memories of extraordinary doings associated with its worship. So here as well is a group of relations that is figured by a sign and that cannot be separated. M. de Molinari is quite right when he says, "if one could penetrate into the souls of a crowd, no doubt one would make strange discoveries there. It would be seen that its concept of religion differs only in form from what this was in pagan times."222

The difference that exists between primitives and moderns resides above all in taste for a more aesthetic representation. The savage is persuaded that his sketch, as crude as it may be, perfectly well represents the personage whose memory he wants to conserve. ${ }^{223}$ Today we are more demanding: it can be seen that these aesthetic demands belong to intellectual development [processus] and that they do not include affective states of a religious order. The character of the sign is notably weakened by the character of the work of art. ${ }^{224}$

\footnotetext{
221 Axiom 47 [§205].

222 Religion, 2nd edition, p. 165. I think that the eminent economist is wrong when he limits his observation to crowds; it has a more general application.

223 M. Flach, lesson of 18 March 1896.

224 We know with what energy certain critics denounced for their irreligious character the greatest works of Raphael and the majority of 16th century Italian artists. In these discussions not enough attention has been paid to the principle indicated here: when religious forms intellectualize, they lose their power over souls.
} 
Occult preoccupations must be noted among the survivals from the primitive way of thinking, which cannot yet entirely leave the human spirit. ${ }^{225} \mathrm{To}$ want to reach a person or a thing by putting one's self in relation to its sign is a desire that does not rise above Dahomey fetishism. The permanence of such a prejudice, which is constantly reborn, shows the force of the logic of imagination.

One curious consequence of this doctrine can be drawn for the explication 1024 of poetic monsters and metamorphoses. They | "were the necessary result of this incapacity to abstract the form and the properties of the subject. Guided

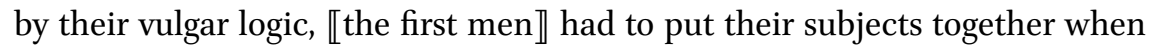
they wanted to bring forms together, or destroy a subject in order to separate its first form from the opposed form to which it was joined."226

Vico remarks quite rightly that at the beginning the figures of language were not figures, but the natural expression of men. ${ }^{227}$ Later on, when the mind had become accustomed to abstractions, it could distinguish between proper and figurative meaning. At this moment a phenomenon occurred on which modern science has insisted a great deal: poetic figures were often interpreted in a prosaic way, and many nonsensical interpretations flowed from this. What has not been written about the famous miracle of Joshua! All contemporary interpreters agree in seeing this tale as simply a misunderstanding. ${ }^{228}$

If one cannot concede to Vico that fables are, in general, past history, still it must be recognized that he rightly showed that the ancients had a great deal of trouble separating poetical and historical compositions, fiction and narrative [récit]. In antiquity, as in the Middle Ages, authors hesitated to invent entirely imaginary characters analogous to those of our modern novelists. "Tragedy took for subjects characters from poetic history: ancient comedy put onto the stage famous men who were still alive. Finally the new comedy, born when the Greeks were the most capable of reflection, created entirely invented characters." Dante composed his Divine Comedy with "real characters and historical facts." 229

In the history of this transformation evidently one must put to the side whatever belongs to prejudice, literary fashion, or academic rules, to consider only what is really living. Vico did not make this distinction well, for if Dante had,

225 Is not the platonic theory of ideas also such a survival? Things owe their reality to their resemblance to a perfect type: as signs, they participate also in the active force of this type.

226 Book II, chapter 3, § 2, p. 403 [§ 410].

227 Book II, chapter 3, § 2, p. 403 [§ 409].

228 Renan, Histoire d'Israël, volume I, p. 243.

229 Book III, chapter 5, p. 533 [§ 817]. 
without a doubt, written according to the laws of development of the human spirit [l' esprit humain] in drawing on historical figures, it is also certain that Petrarch made a work of pure literature in devoting a poem to | the Second Punic war. Nonetheless our philosopher connects these two facts which are of quite different sorts.

For peoples of the heroic age, the adventures of famous chiefs form the most compact, best known, and most intelligible group of existing forms to put at the service of narrators. The adventures of war lend themselves easily to the work of imagination because it is always impossible to know what has happened in a battle: two eye-witnesses will disagree. Although the wars of the Revolution and the Empire are quite close to us, it seems difficult to get an exact idea of these great events. In those cases where it is possible to seize the formation of modern legends, one finds that they hardly depend on a slow work of transformation, but that they are formed above all by a fantastic representation provoked from the first moment by violent emotions. It is because I have had occasion to recognize this system of formation that I consider as very doubtful the ideas expressed by Vico on the historical character of fables. In any case, according to the theory developed in the section above, these fables could not have been, at the beginning, the objective description of an external reality, but signs developed out of emotions: these are not histories in the sense that we give the word.

The proper and eternal character of poetry is to represent "the impossible 【that is》nonetheless believable."230 Anything is believable in the adventures of war and the credulity of our contemporaries, who have devoured without blinking the most deceitful memoirs on the prowess of Napoleonic armies, has been no less great than that of the ancient Greeks. The most cultivated spirits show themselves to be a little more demanding as far as plausibility goes: what seems natural to primitives seems to them the height of the incredible and is no longer of interest. In order to satisfy them, the poet creates imaginary characters [personnages], living under the conditions of real life. He recounts "particular adventures that one might of course simply not know about and that for just this reason one finds truthful."231 Extraordinary adventures can be accepted only if they are presented in a very cautious way, so as not to offend too much the cultivated mind.

It should also be observed that primitive peoples do not try to establish | learned differentiations and that they could hardly do so, since their life is

230 Book II, chapter 2, §1, p. $388\left[\S_{383}\right]$.

231 Book III, chapter 5, p. 534 [ $\$ 817]$. 
much more affective than intellectual. "To the character [caractère] of Achilles,

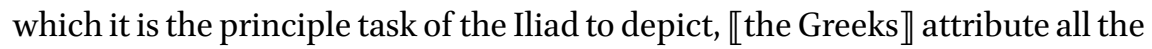
qualities proper to heroic virtue ... In the character of Ulysses, principal subject of the Odyssey, they place all the distinctive marks of heroic wisdom ... They attribute to these two characters particular actions whose renown [célébrité] could strike the attention of a still-stupid people to such a degree that it would be put in one or the other category."232 Here we return to what Vico calls the principle of uniformity: this literature has something impersonal and un-fixed about it, which indeed harmonizes well with a civilization in which man is as yet so little differentiated within the group.

The flaws in imitations of ancient poems made in periods of greater critical development are so striking that the imitations rapidly become tedious. The heroes of classical tragedy speak a very noble language and demonstrate very beautiful sentiments. But they are automatons, they are not sufficiently individualized, they represent types too much.

The same characteristic of generality also finally made classical comedy intolerable: the lawyer, the doctor, the judge, and so on, do not interest us today. We want to be put in contact with perfectly well determined characters [personnages] who depart from the professional types. The same process of individuation led our modern authors to invent purely from the imagination figures that the spectator cannot assimilate to well-known [other] figures.

One must not confuse, as our contemporaries often do, the mixture of history and fable proper to periods in which the imagination reigns in opposition to science, with adulterated interpretations of the past: the latter phenomenon occurs in eras of highly developed intellectualism. Vico was very preoccupied with this sophistication of history, and it was in part to combat errors transmitted by ancient authors about primitive times that he tried to give social science such a deductive form. In the first axiom, he recalls Tacitus' phrase: omne ignotum pro magnifico est. ${ }^{233} \mathrm{He}$ often rebels against the prejudices that 1027 have attributed to primitive peoples a thoughtful life and an intelligence $\mid$ that they could not have had. He has not the least confidence in the virtues of a golden age invented by "the learned." 234

In all adulterated works, we can find an application of axiom 54 [§ 220]: "men interpret unclear or doubtful things they encounter in conformity with their own nature and the passions or habits [usages] that derive from it." Vico applies

\footnotetext{
232 Book III, chapter 4, p. 529 [§8o9].

233 [From Galgacus' famous anti-imperialist speech in Agricola 30: "the unknown always passes for the marvelous."]

234 Book II, chapter 4, p. $439\left[\S_{518}\right]$.
} 
this principle to Greek fables and their different versions. I said in the first section that his interpretation does not seem in general to be tenable, because he attributes to pre-Homeric poets finesse that they did not have. We see, today, many authors treat the history of the Middle Ages in a sophistical way because of the passions that dominate the country. Certain [authors] engage in patriotic action by overwhelming the English of the Hundred Years War with invectives; others sing the praises of the happiness in which workers [ouvriers] lived at the time of the corporations; in the past, democratic demands made by the bourgeois and artisans were the cause of much discussion. Nothing is more difficult, in an impassioned country, than writing history in a scientific way: the milieu dominates even the best minds.

\section{XII}

The problem of anthropomorphism is closely attached to the logic of the imagination, and is of such interest that I thought it best to treat it separately. As is often the case, there are two distinct points of view in Vico, at times he is thinking about how children and primitives might act, and at other times he puts forward laws that are still applicable and are perhaps eternal.

The first men "gave sentiments and passions to material beings and even to the most extended of these beings, to the heavens, to the earth, to the sea."235 We on the other hand, he says, "we still follow a path analogous to these first men, but it is regarding intellectual things, such as the faculties of the soul, the passions, the virtues, the vices, the sciences, the arts. We shape for ourselves the idea of these as so many women (justice, poetry, and so on), | and we attribute to these fantastic beings all causes, all properties, all the effects of the things that they indicate. It is that we cannot set outside [ourselves] intellectual things contained in our understanding without the assistance of the imagination, which helps us to explain them and depict them with a human image."236

This theory does not appear very satisfactory. It is indeed not applicable to scientific notions or even to those whose character has been refined by critical study. Today it seems rather foolish to engage in rhetoric, to invoke the muses to sing, in a question of law, economics, strategy, or agriculture. Philosophical poems these days are not successful. This is because we no longer represent all

235 Book II, chapter $3, \S 1,398$ [§ 402].

236 [pp. 397-398. §402]. 
these things in a human form except as a linguistic survival, conserving them for verbal symmetry, but not as an influence on thought. A transformation has taken place about which something must be said.

I have already called attention to the role played by the artificial milieu in making intellectual combinations. Man finds two kinds of relations in what he makes, psychological and mechanical. The first belong to the domain of vulgar observation, managed by the imagination; the second to the domain of reflective study. Among primitive peoples thoughts "are the expression of passions and sentiments, as opposed to philosophical thoughts, which are the product of reflection and reasoning." ${ }^{237}$ These last have their object above all in the most perfect works of scientific intelligence, which is to say rigorously precise mechanisms, mathematical demonstrations, logical demonstrations, in a word everything that escapes caprice. ${ }^{238}$ The former [psychological relations] are, on the contrary, all sentiment and imagination, at least in their primitive form $\mid$. In our much more complex civilized societies no one can escape the influence of science, therefore mixed forms appear, but the scientific contributions play always an only passive role in these combinations. In any case, science has reached truly and purely scientific form only in a very few cases. More often the name science is given to a group of rather confused more or less scientific reasonings, which are sometimes simply analogic, applied to empirical results: the imagination plays here again a very important role, as much in the formation of the elements as in the demonstrative force attached to certain analogies.

Originally, man could not make sense of things except by constructing representations with what he experienced, which is to say with the most striking psychological manifestations, with emotions and passions. This is the point Vico makes above. He says, elsewhere, that primitive peoples, hearing the noise of thunder, believed that the heavens were speaking to them, that "thunder and lightning were the signs of Jupiter."239 They could understand the world only through the image of their own nature and their own affective states: all noise was a gesture in sound, because they expressed themselves through these same quite crude forms of language [langage].

237 Axiom 53 [ $\$ 219]$. Vico says also in this passage that "men feel first, without noticing the things felt; they notice next, but with the confusion of a disturbed and impassioned soul; finally enlightened by intelligence, they begin to reflect" [§218].

238 "Metaphysics detaches the soul from the senses; the poetical faculty plunges so to speak the former into the latter and buries it there; metaphysics rises up to generalities, the poetic faculty descends to particularities." (Book III, chapter 5, p. 535). This is why Vico cannot admit that there could "be at the same time and to the same degree poets and sublime metaphysicians" [§ 821].

Book II, chapter 2, §1, p. 386 [§379]. 
As man developed himself and accomplished deeds that were more complex, thoughtful, and skilled, he transposed into physical nature the new means he had at his disposal. He constructed the world with his own resources, following Vico's general theory. The new resources had been drawn from his own tools, from methods employed in the arts, and finally from the theoretical studies made of this technology in order to understand and perfect it. From this follows the introduction of relations that I call mechanical, because rational mechanics offers us their most perfect and clear type.

Vico sought to make sense of this opposition. Indeed he said, "just as the metaphysics of reason teaches us that by intelligence man becomes all objects (homo intelligendo fit omnia), the metaphysics of imagination demonstrates to us that man becomes all objects without intelligence (homo non intelligendo | fitomnia); and perhaps the second axiom is more true than the first, since man, in the exercise of his intelligence, extends his mind [esprit] to seize objects and that, in the absence of intelligence, he makes all objects from himself, and by this transformation becomes in himself alone all nature."240

Not only does man explain all actions by the will, but he even transports his organic machinery into the world to designate objects: "the majority of expressions regarding inanimate objects are drawn, metaphorically, from the human body and its parts, or from the human sentiments and passions."241

I said above that according to Vico, the moderns still apply the same procedure to different intellectual things that they represent in the form of women. This is because there are many very important relations in human life that cannot be represented except in passing through a manifestation of the will. For example, one speaks of country [patrie] as a woman, and could hardly do differently: it is not as though great efforts have not been made in our time to give a scientific appearance to the idea of country, but all these efforts have failed pathetically: it is impossible to consider ideas of this sort independently of the psychology of sentiments without comprehensively ruining them. The same could be said of charity, benevolence, and many other affective entities.

Our fathers generally believed that the progress of humanity consisted above all in the elimination of emotional states, that in consequence eventually charity, benevolence, and so on, would become scientific things. It is in this order of ideas that the utilitarian morality has been proposed. It must constitute itself by means of reason and replace the old and too-sentimental morality [morale]. I think that it would not be very difficult to find in Vico arguments in support

240 Book II, chapter 3, § 2, p. 400 [ $\$ 405]$.

241 Book II, chapter 3, § 2, p. 399 [§ 404]. 
of this way of seeing things, which fits very well with the ideal conception of history. But I have already observed that in this philosophy, ideal history is the deadweight that must be separated from the theses destined to last. Vico says about the faculties of the ancient poets, "the peoples who, in this era, were so to speak all body without reflection, were all sentiment in order to feel particular1031 ities, | all imagination to seize and expand them, all invention to connect them to kinds that the imagination had created (generifantastici), finally all memory to retain them. These faculties belong no doubt to the spirit [esprit], but they draw from the body their origin and their vigor."242 If this is so, it is not too clear how the domain of the imagination - a way of representing with volitions, the faculty of producing fantastic kinds-could disappear.

Man cannot become a purely intellectual being. It is for this reason that we find, in all eras, phenomena that remind us of the procedures to which we have given the name anthropomorphism. It was not without difficulty that physics succeeded in eliminating theories about the faculties of atoms, that had been called properties of matter [matière], but that were nothing other than the introduction of psychological entities into the domain of mechanics. The victory is not yet complete for, from time to time, we see unfortunate returns of atomism, which disguises itself in new costumes and cleverly hides the faculties that it introduces. Contemporary physiologists are nearly all anthropomorphists. Those dealing with the nervous system can never stop themselves from endowing the elements they study with will and consciousness. And they think that they therefore have given a scientific explanation of will and consciousness! If they limited themselves to saying that they make use of these constructions because they are convenient and because they seem for the moment the best way of clearly representing the phenomena, there would be nothing to complain about;- - but the dignity of Science does not permit looking too closely and understanding what one is doing.

Must it be said, with Vico, that the method [procédé] of the moderns (which consists in materializing intellectual things) is contrary to the method of the primitives (which consisted in animating material things)?243 The difference is not so great as it may at first appear. The barbarians hardly yet separated the object from the simulacre: today we are obliged to make this separation at least in language. When reflection has arrived at a middle state, it places in things an idea, a notion, an entity, that we seek to know, that we succeed in reaching $103^{2}$ through the exercise of the intelligence, | that we name: each word corresponds

242 Book III, chapter 5, p. 534 [ $\$ 819]$.

243 Book II, chapter 3, § 1, p. 398 [§ 402]. 
to an objective reality. Primitive peoples have not yet achieved abstraction and they still mix together the idea and the object; as for the most advanced philosophers, they realize their abstractions.

It is impossible for us to speak about anything without figuring it materially; this is what happens with abstractions that we are obliged to connect to the wills of fantastic beings. We are different from the barbarians only in that we bring these beings out of the sensible world [milieu] in order to make them inhabitants of a world of imagination without poetry. Vico was quite right to say that the method [méthode] followed by the moderns does not have the sublime character of that of the ancients: it engenders at once error and pedantry.

It is only in taking the greatest precautions that it is possible to avoid the errors that this logic of the imagination, always present and always ready to impose itself, engenders when scientific logic shows itself to be even momentarily relaxed. ${ }^{244}$

It remains to examine why the ancient poets, in animating nature, produced such sublime inventions. Vico speaks frequently of this quality of old poetry but does not give us any very clear explanations. Nonetheless this important rule must be remembered: "the poetic sublime must always have something of the popular."245 One can conclude from this that it is closer to psychological methods of representation than logic or science, but that does not exhaust the subject.

Vico's observation allows us to understand why A. Comte and his disciples were so sovereignly ridiculous in their posturing attempts at religious elevation. It is because they belonged to the classes absorbed by intellectual labor and incapable of understanding things in a popular way. We see $\mid$ an analogous phenomenon in the Middle Ages. Ecclesiastical writers rarely had sublime ideas, their lives were lived far from the people, and their work shows that they were more or less totally ignorant about the contemporary world.

In Vico's mind the sublime is proper to primitive civilizations and it cannot occur again before the cycle of ideal history swings back to the time of barbarism. And Vico indeed several times causes the exceptional power of the sensory faculties of primitive peoples to intervene. He supposes that they were

244 The mind has a very difficult time not putting a being behind a word; one of the most curious examples of this superstition is offered to his by the history of the concept of milieu. This word is used to designate not a thing, but an ensemble of relations, and yet it has it any the less been made a character that the positivists have divinized, the Great Milieu? I read somewhere that man is submitted to mesological influences. Thus the evolution is complete: relations are synthesized with an abstract word, which becomes a being, and engenders influences—-thus everything is backwards. Oh! Scientists! Scientists!

Book III, chapter 4, p. 530 [§809]. 
differently organized than we are. "Providence ... wished that in the age when man had fallen into a state of brutality, he might be conserved by the most active and subtle senses and that then these senses would weaken when the age of reflection arrived, and that this faculty of prevision [prévoyante] would in turn protect the body. From what proceeds it must be understood why heroic descriptions, such as those of Homer, were so brilliant and striking that all the poets of later ages could not imitate them, and far less equal them."246 In other passages, he speaks in the same way about the extraordinary memory and strong imagination of barbarous peoples.

I do not think that it would be easy to demonstrate this physiological degeneration. In any case, experience would show in the century following Vico's death that the most elevated lyric poetry was still possible.

Still there is something right in Vico's ideas: the way in which primitive peoples feel is much more poetic than the way in which reflective ages represent things. The first animate nature without decomposing it, while the classics superimpose on nature a world of fictive characters, whose intervention is the most distasteful thing imaginable: genies, fairies, nymphs, all make any sort of description odious. Modern poetry has rediscovered nature and put itself directly in contact with it: it has been necessary to animate nature to some degree, because of the necessity of using a language full of images drawn from affective states, but ways have been found not to reproduce the forms of the past; in our time, it would have been impossible to remake a natural mythology, even a barbarous one, without quickly arriving at the flat mythology of our classics. ${ }^{247}$

1034 Modern poetry and primitive poetry can be compared also according to another characteristic: the sublime demands that the soul feels emotions that belong to the domain of fear, however little they may be developed. Barbarians experience terrors that seem to us quite childish when we visit the places that they peopled with fantastic beings; classical literature strove to describe the places that tradition had consecrated and could not succeed in provoking any emotions. To rediscover the sublime, one must put one's self into environments [milieux] that are quite different but still able to provoke in our civilized souls emotions analogous to those that primitive peoples had known. The sea, the mountain, great solitude, are capable of giving this impression of awe [sousterreur] (if one may use this barbarous word), without which there is nothing sublime. $^{248}$

246 Book II, chapter 7, § 2, p. 489 [-49o. §707].

247 There is a remarkable example of creations foreign to the theory of returns in ideal history.

248 In the third book, Vico tries to show that one can no longer find in civilized milieus 


\section{XIII}

The transformations of law occupy a large place in the New Science. One must first of all understand a certain number of important notions. Vico borrows this definition of civil equity from Ulpian: "it is a presumption of law [droit], which is hardly known naturally by all men, but only to a small number of men who, uniting wisdom, experience, and study, have learned what is necessary for the maintenance of society. It is what we call the reason of State."249 On the contrary, "the natural equity of human jurisprudence in its largest development is a practice, an application of wisdom to useful things. For wisdom, taking this word in its broadest sense, is only the science of making of things the uses that they have in nature." 250 These formulas are not very satisfactory because the first supposes that the rulers of primitive peoples already possess a culture sufficiently advanced to reason about the maintenance of society, | which could not be the case except in a state of civilization much closer to our own. Ulpian lived in an era in which Roman jurisprudence was already constituted. This was far from a primitive time! As for the second definition, we can see that it depends on the false idea that the old philosophy had of Justice. Vico believed, as did nearly everyone else, that the Good exists and that man can come to know it, at least within the limits imposed on his faculties by weakness. I have already insisted on the importance of this theory in the New Science.

Juridical change is defined in yet another way in axioms 112 and 113: "The certitude of the law [la loi] is only a faded shadow [ombre effacée] of reason derived from authority. We find laws harsh in their application and yet we are obliged to apply them because of their certitude. Certitude is the principle of natural inflexible jurisprudence in the barbarous ages and its rule is civil equity.- In the laws, the true is a certain light by which natural reason illuminates us." 251

These differences are founded on a psychological law and a providential decree. Vico says in axiom 9 [ $1_{137}$ ]: "unable to know the true, men try to arrive at the certain so that, if intelligence cannot be satisfied by science, the will at

episodes analogous to those that Homer used: "poetics or critique can made cultivated minds, but cannot give them grandeur." (Book III, chapter 5, p. 535 [§ 822]).

249 Axiom $110[\S 320]$.

250 Axiom $114[\S 326]$.

251 [As Menasseyre notes, this is from axioms 111-113, and is also somewhat embellished at the beginning: "La certitude de la loi est une ombre de la raison (obscurezza) appuyée sur l'autorité. Nous trouvons alors les lois dures dans l'application, et pourtant nous sommes obligés de les appliquer en consideration de leur certitude." pp. 349-35o. §321323.] 
least relies on the conscience." At the end of axiom 114 [ $\$ 328]$ we read: "As the nations are obliged to live for many centuries still unable to know the truth and natural equity, Providence allows that in the meantime they pursue certitude and civil equity, which follow religiously the expression of the law, even when it becomes harsh and rigorous in its application, in order to assure the maintenance of human society." This thought is again reproduced in a somewhat different form further on, "Men were for a long time unable to know truth and reason, sources of interior justice, which alone can satisfy intelligence. But in waiting, they govern themselves through the certitude of authority, through the common sense of human kind, with the evidence on which rests the conscience of all nations. Thus, in a certain sense, the New Science becomes a philosophy of authority, source of external justice."252

Today, we cannot see things as Vico did; we can no longer speak of a move${ }_{1036}$ ment toward the Good. | We see that with transformations the sentiment of justice received a great development among men. We can say that this sentiment furnishes energy necessary for struggle, but we can no longer recognize that it might be a force having a constant direction, capable of leading the world in a given direction.

Originally, it does not seem that authority had any sort of idea of justice as a justification. In heroic law [droit] Vico finds only the law of force, "the law of Achilles that finds its reason entirely at the point of his spear." ${ }^{253}$ Our philosopher has undertaken a detailed study of the Homeric characters and he objects strongly to the errors of those who have interpreted the manners [moeurs] of the past in light of modern theories. "They have carried into the heroism of the first ages three ideas that are natural to minds enlightened and softened by civilization: the idea of a justice reasoned and led by the maxims of Socratic morals; the idea of this glory that recompenses the benefactors of human kind; finally the idea of a noble desire for immortality" 254 Achilles' virtue "is the susceptibility, delicacy in the point of honor, in which duelists expressed all their morality at the period when ancient barbarism reappeared during the Middle Ages." 255

In such long-ago times, authority was pure and simple; (it nonetheless cannot be identified with simple arbitrary free will, since it had a certain regularity to assure relative stability for society). Yet one might then ask how to pass from the certain to the true, from heroic authority to reasoned authority: it seems

252 Book I, chapter 4, p. 365 [in fact $366 . \S 35$ o].

253 Book IV, chapter 1, §4, p. 555 [§ 923].

254 Book II, chapter 6, § 8, p. 477 [§666]. Cf. the first chapter of Book III.

255 [p. 477, §667]. 
that this movement is not intelligible because it does not take place within the same kind and because, beginning with an amoral state, humanity arrives at Justice.

Many authors have thought it necessary to introduce into primitive civilizations philosophical ideas that were absent from them. Sumner Maine had no problem doing so. He said that law had been formed first of all from themistes, sentences based "on an inspiration from above in the mind of the judge, at the moment in which he pronounces his judgement."256 It seems to him entirely natural to think that these decisions were reputed just because of their divine origin. But Vico notes | that in the Iliad the gods do not seem more morally advanced than men. ${ }^{257}$ It is none too clear what idea of justice could correspond to such an inspiration. Finally Sumner Maine can invoke no text to support his opinion. Aristotle speaks of royal judgements and tells us that kings swear an oath in raising the scepter-but what does this mute language mean? Is it not the equivalent of the language of the chancelleries, a simple sign of command? ${ }^{258}$

It is regrettable that Vico did not apply here his law of comparison, which might have furnished him with useful clues. The authority of the heroic times could be compared with that of the High Middle Age. If there is an era in which the idea of Justice is completely absent, it is surely that one. Authority pursued its own satisfaction, sought what profits its power could bring, and considered the administration of justice above all as a revenue source: it is one of the most curious chapters in the history of the State.

What is the nature of the end toward which juridical change directs itself, meaning here a provisional and real end? Vico recalls a phrase from Dio Cassius: "Custom is like a king, law a tyrant." 259 This formula is of great importance for determining juridical ideas; we must pause over it because it is clear that, in Vico's mind, the truly natural regime is that of custom.

When a reform takes place in our own time, the country finds itself divided into two parties: those against whom the law has been made submit because they cannot do otherwise and because they are not strong enough; ordinarily they hope to take their revenge later on;- - as for the victors, they pretend that Right [Droit] is identical to their desires, their interests, and they hurry to profit from the advantages that power [la force] gives them. ${ }^{260}$ If at the end of

256 Ancien droit, fr. trans., p. 8 [Maine, Ancient law, 3].

257 Book III, chapter 1, p. 516 and book IV, chapter 4, §1, p. 576 [§967].

258 Politique, book III, chapter 9, §7 [Politics, 84-85].

259 Axiom $104[\S 308]$.

26o I understand here the word power [la force] in the general sense; any law, voted on as reg- 
several years the new rules have indeed been accepted and pass into habit [les ${ }_{103}$ moeurs], then their origin is no longer a source of concern, they $\mid$ are taken such as they are and become customary [des coutumes]. It even happens rather frequently that the people who had fought against the change become the best defenders of the new situation.

During the provisional period, the law is an annoyance for many people: it appears still as an expression of the will of a group. Later on it will be only a fact, that one can consider in an objective way, without discussing the legitimacy of its origin and without seeking to know exactly the reasons that brought it about. This transformation is striking for the institutions born out of the Revolution: few people interest themselves in the causes for their adoption. These causes are frequently very difficult to reconstruct, and when we can do so, often they turn out to have been rather unsavory; - but today, it is no longer in general of great importance to know if the desire for wealth, if passions and hatreds, had a greater or lesser influence on the laws voted on in this period. We are no longer living in 1789 and these things must be evaluated from today's point of view.

When law has become custom, generally very mediocre reasons suffice to justify it. ${ }^{261}$ The real reason for its maintenance is that it has existed long enough to have been accepted and to have been put into relations with new practices [usages]. It is not greater or lesser conformity with the ideal of Justice that renders it good; but we can say that it no longer instigates protests sufficient to excite the sentiment of justice in the country to a significant degree.

Once this has come to pass, the rule no longer appears to be an exterior order founded on coercive force, but seems rather to be purely natural: for this reason the philosophers are not entirely unreasonable to claim that we can ascribe the most general and least contested practices [usages] to human nature. Vico 1039 says, | "Divine wisdom has no need of the force of laws; it prefers to lead us by customs that we freely maintain, because following them is following our nature." 262 When one abandons traditional moral theory, one sees that natural

ularly as may be by a parliament, is only the manifestation of the power of the party that demands it.

261 Ordinarily the reasons given are historical absurdities.

262 Book v, chapter 4, p. 639 [ $§ 1107$ ]. Cf. book II, chapter 5 , $§ 1$, p. 442. Compare to a famous passage from Aristotle: "The law has no power to make itself obeyed but that of habit, and habit is not formed except through time and years" (Politique, book II, chapter $5, \S 14$ ) [Politics, 49]. When custom has been thus established, it acts on our conscience and engenders our manner of speculative thinking through the ideogenetic laws: it is in these conditions that one can say that the manner of living engenders the consciousness [la conscience] and that the social structure is reflected in the human mind [espirt]. Vico's custom, Aristotle's law, [1039] are, in some way, assimilated by the individual and produce in our brains their intellectual consequences. 
law does not justify customs, but that it is only a way of translating customs into metaphysical language in order to group them, coordinate them, and deduce detailed rules from them. Justice no longer appears as an end toward which one goes, nor as an interior force that moves us; it exerts itself only intermittently, when we feel the need to change our juridical rules: it is no more in the final end than in the starting point: it is only in the movement. ${ }^{\text {A29 }}$

Ancient law presents a very great difficulty on which Vico insists a great deal without being able to give a satisfactory explanation, and one must also not be surprised to see him invoke Providence in order to account for the rigidity of primitive jurisprudence. "These inflexible judgements were necessary for the times in which heroes put reason and good law [bon droit] in force. To forestall complaints, tricks, and murders, Providence saw fit to constitute justice as the precise expression of ceremonial [solennelle] forms." $263 \mathrm{He}$ believed that this jurisprudential practice was a survival; "generally divine things are expressed by consecrated formulas in which not one letter can be changed; thus in the ancient formulas of Roman jurisprudence, in imitation of sacred formulas, it is said: one comma too few, the case is lost." We get not much further in recalling the importance of the oath in ancient proceedings; Vico notes the difficulty because he again invokes "the design of Providence, which made it so that in heroic times, the word was considered irrevocable."264

To this first difficulty we must add that of explaining the fiction of law, by means of which it is possible to conserve venerated texts while applying them in a new way to new situations. It does not seem that anyone has yet managed to give $\mid$ complete and scientific interpretations of these phenomena. Sumner Maine indeed tried to formulate laws of the general evolution of jurisprudence that he found to be applicable in an approximate way to Rome and to England; but he did not try to show that his theory applied to other countries, he did not even try to account for the mechanism of these fictions; he showed their historical importance and believed that their utility explained their existence.

In Vico we find a more interesting perspective on this mechanism, which he quite ingeniously compares to successive forms of expression. "Man being properly nothing but intelligence, body, and language [langage], and language being as the intermediary of the two substances constituting his nature, the certain in matters of justice was determined by acts of the body in the times that preceded the invention of articulated language. Since this invention it has been [determined] by verbal formulas. Finally, human reason having taken on its full

263 Book IV, chapter 4, §1, p. 575 [§ 966].

264 Book IV, chapter 4, §1, p. 577 [This line is in square brackets in Michelet and finds no clear analogue in the original text. §968]. 
development, the certain will be confounded with the true of ideas relative to justice, which will be determined by reason according to the most particular circumstances of the facts." 265 Thus we see that right [droit] has followed an evolution related to the laws [lois] that bind expression and thought.

For Vico, these laws are of major importance; the formation of intelligible kinds was indeed in his eyes preceded by a long period of work on languages [langues]. "The poets having first formed poetic language by the association of particular ideas, the peoples then formed the languages of prose by bringing together under a single word-like the species to a kind [comme les espèces au genre] — the parts that poetic language had put together ... This abbreviated method gave more activity to minds and made them capable of abstraction; later could come the philosophers who, prepared by this vulgar classification of words and letters, worked on that of ideas and formed the intelligible kinds." ${ }^{266}$

The common people have a sort of sovereignty over civilized languages. "The absolute power of peoples over languages extends to a relation to legislation: the people gives to laws the meaning it likes and the powerful must manage as best they can to follow | the laws in the meaning given to them by the people. Monarchs cannot take from peoples this sovereignty over languages [langues]."267

Thus the mechanism of juridical change is ordered by the mechanism of languages [commandé par l' outillage des langues]; this is what allows us to understand ancient Roman law, what Vico calls "a serious poem that the Romans performed on the forum." 268 Jurisconsults make use of techniques identical to those of fable-writers in order to stage new combinations. "Unable to create abstract forms through intelligence, they imagined corporeal ones and supposed them animated according to their own nature. They realized heredity [hérédité] in their imagination as sovereign over heritage and placed her entirely in each of the effects of which it was composed ... The first jurisprudence was entirely poetic; through a series of fictions it supposed that what was not yet done was already done, that what was born was yet to be born, that death was living and vice versa. It introduced a host of disguises, veils that cover nothing, rights [droits] translated into fables by the imagination. It made all its worth consist in finding fables well enough imagined to rescue the gravity of the law [loi] and apply right [droit] to fact."269

265 Book IV, chapter 7 , 2 2, p. 611 [ $§ 1045]$. Already quoted partially in X.

266 Book II, chapter $3, \S 5$, p. $423[$ [ 460 o].

267 Book IV, chapter 2, §2, p. 559 [§936].

268 Book IV, chapter $7, \S 2$, p. 608 [§1037].

269 Book IV, chapter 7, § 2, p. 607 [§1035]. 
The judge, unable to follow philosophical reasoning, has no guarantee against the possibility of error but the very exact attribution [propriété] of terms. "Barbarians, having only particular ideas, are satisfied so long as the terms of the law [loi] are precisely applied. Such is their idea of right [droit]."270 Vico says again, "in aristocratic governments, the cause (exterior form) of obligation consists in a formula through which one seeks a guarantee in the precision of speech and the attribution of terms."271

In order to understand juridical change it is absolutely necessary to follow at the same time the mechanism that men have available and changes of a psychological order. "Wisdom is the faculty that dominates all doctrines relative to the sciences and the arts that $\mid$ make up humanity. Plato defines wisdom as the faculty that perfects man ... Wisdom starts with the muse, defined by Homer, in a remarkable passage of the Odyssey, as the science of good and evil; this science was then called divination ... Afterward, wisdom was attributed to men famous for having given useful advice to human kind; such were the seven sages of Greece. Later, wisdom passed into the opinion of the men who organized and wisely governed States in the interest of nations. Yet later, the word wisdom came to signify the natural science of divine things, that is to say, metaphysics." ${ }^{272}$

This wisdom is not necessarily represented by men who possess civil authority. Most often it belongs to thinkers who live independently, whose sayings are collected as maxims.

In the history of institutions, movement is perhaps easier to understand than conservation. Not all peoples have had the Romans' superstitious respect for formulas. Causes that could have determined the conservative character of their legislation must therefore be investigated. Vico saw well that everything here depended on their aristocratic constitution. "Secrecy is the soul of aristocracies," 273 he said, thinking probably about Venice. "The conservation of orders carries with it that of the magistrates and priesthood and, in consequence, that of the laws and jurisprudence ...; knowledge of laws was the last privilege that the patricians ceded to the plebeians."274 If there is a privileged body, charged with keeping and guarding the laws [lois], able to keep the law [droit] secret, not much will change in juridical expressions: the interest of this body is indeed

\footnotetext{
270 Axiom 3 [In fact, axiom 111, §322].

271 Book IV, chapter $7, \S 2$, p. 610 [Michelet has truncated the text substantially here. See $\S 1043-\S 1048]$.

272 Book II, chapter 1, § 2, p. 376 [ $\left.\S_{365}\right]$.

273 Book IV, chapter $3, \S 5$, p. 568 [§953].

274 Book IV, chapter 5, §3, p. 589 [§ 999].
} 
not to allow any interference with the formulas of which it is the proprietor. Experience proves that, everywhere, magistrates are very opposed to innovation.

It does not seem that devotion to words [la religion des paroles] has a single cause, producing palpable effects in all countries. Where it does exist, it did not come about all at once; it was necessary that the body of formulas had been considered finished (at least in a general way). We know from the history of the Israelites that this moment arrived rather late for them and under the 1043 influence of very particular historical reasons |.275 Sumner Maine ingeniously connects Roman law to the moral theology of Catholicism. ${ }^{276}$ It really seems that here there has been a tradition and that it is the practice of jurisconsults that engendered certain habits of thought among Latin theologians. But the history of Christianity presents a great difficulty; it is not known in what era and under what influences the Canon was stopped: it is after this moment that devotion to words took on a preponderant importance.

This moment is characterized by the death of sentimental associations and the incontestable development of regular associations undertaken according to some science or other, a science sometimes very absurd from the perspective of the moderns but very respectable for the ancients. Antique decisions did not need to be very precise, as long as they were not treated in a scientific way; they served only to recall certain affective states: they were, in a sense, quite vague, because they were only signals for emotions; they were extremely narrow, if they are examined in their scientific meaning, because they could not yet include the definition of kinds, but only appreciations of particular things. The learned would not have been able to get their theories adopted if they did not have ingenious ways of using formulas. In each particular case, the historical origin of the methods must be sought out.

In closing let us examine Vico's idea of fully developed jurisprudence: "Human judgements are not blind and inflexible like heroic judgements. The rule they follow is the truth of facts ... Monarchs, in these judgments, glory in being supe-

275 It would be impossible to attempt a solid theory on the general history of law without having conducted a deep study of the Talmud.

276 Ancien Droit, p. 335. Vico says that the doctors of the Middle Ages operated like Roman jurisconsults; they sought to "protect the clients and prepare them to provide a detailed account of the contested case" (Book IV, chapter 3, §1, p. 561 [§ 939]). 
rior to the laws and in depending only on their conscience and God."277 He says elsewhere: "Constantine | entirely abolished the formulas and it was recognized that any motive of equity prevailed over the law. So much are minds [les esprits] disposed to recognize in a docile way equity under human governments!"278

Vico here only puts in philosophical form current practice: sovereign courts had it recognized that they were, to a certain degree, the successors of the sacred council and that they could judge according to conscience; the 18th century did not end without seeing this principle applied to criminal judgments by jury. It is not useless to recall here that Aristotle had a completely opposed idea of judgement and that he recommended leaving judges as little latitude as possible. ${ }^{279}$ The experience of Greek tribunals had taught him the danger of decisions taken according to conscience.

In my opinion, the question must be considered from a point of view very different from Vico's. These judgments, in which monarchs placed themselves above the laws, were never anything but exceptions; we cannot therefore consider them as characteristic of an advanced state of jurisprudence. The Neapolitan philosopher, who believes in the existence of absolute Good, must think that the world works in order to attain full consciousness of this Good; this, we can no longer entertain. If equity seems sometimes to demand that certain tribunals not follow the laws, we must see in this, according to the theory developed above, a movement that tends to change the rule: this movement exists at all times and always happens in the same way, beginning with a particular case, an extraordinary fact.

Vico recognized perfectly well the character of certain formulas, too old to be well understood: "Ancient laws seem to address one man alone; from a first case, they extend to all the others, because the first peoples were incapable of general ideas; they could not conceive of them before the facts that called them forth presented themselves. In the trial of the young Horace, the law of Tullus Hostilius is nothing other than the sentence carried out against the illustrious accused by the duumvirs, who had been created by the king for this judgement ... The examples must at first have been real; abstract examples came later. But when | general ideas had been acquired, it was recognized that the essential property of the law [la loi] must be universality, and this maxim of jurisprudence was established: legibus, non exemplis, est judicandum." 280

277 Book IV, chapter 4, §1, p. 578 [§974].

278 Book IV, chapter 5, §3, p. 591 [Sorel omits "naturelle," which modifies "l' équité" in Michelet and in Vico, as well as removing Michelet's italics. §1001].

279 Rhétorique, book I, chapter 1, §§6-7.

28 o Book II, chapter 3, §6, p. 433 [§500-501]. 
According to an opinion widely held, and notably by Sumner Maine, change in law is, in advanced civilizations, the work of the legislator alone. This theory does not account for the facts: most often the legislator intervenes only to regularize and coordinate: his role is that of an editor, putting scattered and sometimes discordant decisions into juridical language. The true movement must be grasped where particular decisions are made.

Particular judgments do not come in two kinds: these deriving from the ignorance and simplicity of primitives incapable of generalizing and those revealing a full awareness of equity among civilized princes. In all periods, they are the source of law [droit] and they constitute the normal means through which institutions modify themselves.

As relations become more complex in modern society, the need is felt to provoke these juridical movements to a greater degree; and they are provoked in the way I have just described, and which is one of the clearest manifestations of historical materialism: theory follows practice and does not precede it. In order that law may adapt itself easily to new needs, everywhere people hurriedly create exceptional jurisdictions, foreign to what is taught in the schools and to the traditions of professional magistrates. Often fanatics of unity have demanded a return to the principles of the Revolution and the unification of all tribunals. We see, in the present moment, many authors attacking the jury. In fact, the number of secular commissions [commissions laïques] is still increasing. ${ }^{281}$

Since the progress of large-scale industry has modified to such a degree the 1046 conditions of the labor contract, there has often been a desire to bring $\mid$ the civil Code into conformity with new needs; but this has never gotten past quite empty declamations about labor, because it is impossible to say what must be done. Effective measures taken up to today have been those that different countries have realized by instituting either mediating councils or labor chambers: these new organs have not yet produced very much, but this is in part because they have been made to function in too judicial of a way and people have wanted from them what they cannot give. They ought to be thought of as commissions charged with elaborating particular opinions, much more than preparing transactions. When the general public has become familiar with the difficulties that industrial practice presents, when many more examples have

281 In the milieu from which these commissions recruit, one nearly always finds in a clear way phenomena that can be recognized as the origin of law [droit]; opinions follow one another and coordinate not in a logical or scholastic way, but in virtue of sentimental affinities. Aristotle had seen this character very well in criminal justice in Athens; he says that the gravity of a crime was measured in the terror and the pity that its telling provoked among those who heard it (Rhétorique, book I, chapter 14, §3). 
been examined, it will be possible to think about formulating new rules and drawing up a labor Code. At the present time it is not known what should go into this Code.

The endpoint for these commissions is above all to put conflicts in juridical form, to specify them, to recognize exactly the forces at work and to define them. But the name they take (arbitration councils, conciliators, etc) must not hide from us the very foundation, the fundamental cause of the movement, which is the class struggle for the conquest of rights [droits]. I have already had occasion to observe that Vico perfectly well distinguished between the struggle for conquest of the advantages of power and the struggle for rights. ${ }^{282}$ It is a distinction of great importance, which ought to be always present in our minds when we examine the history of contemporary conflicts from the point of view of the evolution of juridical ideas.

282 From the point of view of historical materialism, it would not be very exact to speak of struggle for the law [droit]. 